\title{
Interaction of enzymes with lignocellulosic materials: causes, mechanism and influencing factors
}

\author{
K. S. Baig*
}

\begin{abstract}
For the production of biofuel (bioethanol), enzymatic adsorption onto a lignocellulosic biomass surface is a prior condition for the enzymatic hydrolysis process to occur. Lignocellulosic substances are mainly composed of cellulose, hemicellulose and lignin. The polysaccharide matrix (cellulose and hemicellulose) is capable of producing bioethanol. Therefore, lignin is removed or its concentration is reduced from the adsorption substrates by pretreatments. Selected enzymes are used for the production of reducing sugars from cellulosic materials, which in turn are converted to bioethanol. Adsorption of enzymes onto the substrate surface is a complicated process. A large number of research have been performed on the adsorption process, but little has been done to understand the mechanism of adsorption process. This article reviews the mechanisms of adsorption of enzymes onto the biomass surfaces. A conceptual adsorption mechanism is presented which will fill the gaps in literature and help researchers and industry to use adsorption more efficiently. The process of enzymatic adsorption starts with the reciprocal interplay of enzymes and substrates and ends with the establishment of molecular and cellular binding. The kinetics of an enzymatic reaction is almost the same as that of a characteristic chemical catalytic reaction. The influencing factors discussed in detail are: surface characteristics of the participating materials, the environmental factors, such as the associated flow conditions, temperature, concentration, etc. Pretreatment of lignocellulosic materials and optimum range of shear force and temperature for getting better results of adsorption are recommended.
\end{abstract}

Keywords: Biofuel, Bioethanol, Adsorption, Mechanism, Shear force

\section{Introduction}

Plant dry matter is called lignocellulosic material or biomass because this material consists of cellulose, which is closely associated with lignin. Lignocellulosic materials are abundant on earth with their annual production around 1.815 billion tons (Dahmen et al. 2019). Agricultural residues and forestry wastes represent more than $90 \%$ of lignocellulosic material in the world (Saini et al. 2015), where lignocellulosic biomass contains up to $75 \%$ of polysaccharides (Marriot et al. 2016). Polysaccharides are long chains of polymeric carbohydrates where monosaccharide units are bound with each other by glycosidic

*Correspondence: ksbaig@grenfell.mun.ca

School of Science and Environment, Memorial University, Grenfell

Campus, Corner Brook, NL, Canada linkages. Lignocellulosic materials are receiving huge attention as a renewable and economical alternative to fossil resources for the production of various valueadded products such as biofuel, hydrogel, and specialty chemicals.

The basic steps involved in the production of biofuels from biomass include: pre-treatment, saccharification, fermentation, and distillation. Pretreatment is designed to break down the complex carbohydrates into cellulose, hemicellulose and lignin so that the cellulose and hemicellulose can be hydrolyzed by enzymatic catalysis. Lignin consists of phenols, which is not fermentable; therefore, lignin is separated and it is used to provide process heat and electricity for the industry. Distillation is the product purification step. The core unit operation in the hydrolysis process is the saccharification which 
starts with the desorption of enzymes. The attachment of enzymes or cells to the surfaces of biomaterials (live or dead) is adsorption. Adsorption is a key phenomenon in modern industry such as: (1) catalysis, (2) clarification of sugar (3) pollutant separation (air purification, hard water softening, wastewater treatment, etc.), (4) biomaterials implantation, (5) and in medicine. In addition to these, adsorption indicators are gaining popularity in both research laboratory and industry. During enzymatic adsorption, the interaction of enzymes could be specific and non-specific to adsorb or to oppose the detachment from the biomaterial surface (Vladkova 2010; Dhowre et al. 2015; Navarro-Sanchez et al. 2019). Poor adsorption results in less hydrolysis and hence less production of biofuel. Similarly, poor adsorption results in unsuccessful implantation of biomaterials. The interactions at the molecular level that regulate enzymatic adsorption to biomass are not completely understood (Taegtmeyer 2012; Jalak and Väljamäe 2014; Donaldson and Vaidya 2017; Bonnin et al. 2019). The comparative influences of specific and nonspecific adsorption mechanism of enzymes are dependent on the surface characteristics of the biomass, the provided flow rate and the environmental conditions.

The combined production of biofuel by USA and Brazil is $49.6 \%$ and $38.3 \%$ of the total international production, respectively (Coyle 2007). There is a forecast by International Energy Agency (IEA), which indicates biofuel production is expected to increase 165 billion liters by 2023 . In this huge market, the share of bioethanol is going to be 119 billion liters (Voegele 2019). Table 1 compares the annual growth of biofuel production against its required growth rate for the top three largest bioethanol producing countries.

It would be interesting to note that the annual growth in demand is more than the required growth in production of biofuel. Canada is also in the production and use of biofuel because of an estimation that the use of biofuel can reduce greenhouse gas (GHG) emissions by approximately $30-96 \%$ as that of gasoline,

\begin{tabular}{|c|c|c|}
\hline \multirow[t]{2}{*}{ Country } & \multicolumn{2}{|l|}{ Production } \\
\hline & Annual growth (\%) & $\begin{array}{l}\text { Growth } \\
\text { required } \\
\text { (\%) }\end{array}$ \\
\hline USA & 1 & 6 \\
\hline Brazil & 3.5 & 6 \\
\hline China & 16 & 17 \\
\hline
\end{tabular}

Adapted from IEA (2019) depending on the type of biomass and the biomass conversion technology used (Fulton et al. 2004; Khattab and Watanbe 2019). In fact the use of ethanol in Canada has increased from 3140 million litters in 2018 to 3250 million litters in 2019. Refineries produced 1755 million litters in 2018 and 1830 million litters in 2019. Obviously, Canada follows the same trend of less production than demand as that of large ethanol producers. If biofuel is produce by grains (corn, wheat, etc.), it creates food scarcity for people. If it is produced from corn stover, animal food supply is in trouble. Similarly, use of wood will risk tree conservation. If Canada uses waste lignocellulosic materials (agricultural waste, forestry waste) for the production of bioethanol, the cost of domestic ethanol will reduce. For example, Canada is producing 37.5 million tons of wheat straw, which in turn can produce 13.125 billion liters of ethanol (Baig 2016a). The annual allowable cut (AAC) for Canadian forest growth is 250 million $\mathrm{m}^{3}$, which can produce 52,000 million liters of biofuel (National Forestry Database 2017). Only $25 \%$ of wheat straw or $10 \%$ of AAC can produce Canadian total ethanol demand. Therefore, Canada can use indigenous lignocellulosic waste materials to produce bioethanol without being a burden on grain foods supplies, animal feed cycle or on tree conservation. Lignocellulosic feed stock materials need pretreatment to enhance adsorption of enzymes to the lignocellulosic substrates; the more the specific adsorption, the more is production of bioethanol through hydrolysis. One of the reasons for the less growth rate in actual production of biofuel is due to less adsorption or less specific adsorption or non-specific adsorption, which can be increased by the greater understanding of the mechanism of adsorption. Another aspect of enzymatic adsorption to a biomaterial (lignocellulosic biomass) surface is that it is a sequential process where initial interactions are weak, reversible, non-productive and instantaneous; with the passage of time, the interplay leads to establishment of productive molecular interactions. The factors involved in the process of enzymatic adsorption, techniques and principles are reconsidered in this study. Knowing the physical structures and chemical compositions of enzymes/proteins and biomass/biomaterials, a conceptual mechanism is suggested which will help researchers to understand the adsorption process more deeply and increase the biofuel production. In the last few years, substantial work has been reported for the process of adsorption of enzymes to lignocellulosic biomass surfaces; however, many questions remain unanswered to win confidence of biofuel producing industry. Some of the questions are addressed in the coming sections. 


\section{Factors influencing enzymatic adsorption (bacterial adhesion)}

Adsorption of enzymes on lignocellulosic materials is a delicate and intricate process, which is influenced by the characteristics of enzymes and adsorbent substrate, environmental dynamics, such as the connected flowing states. A detailed discussion on the factors influencing enzymatic adsorption is given in the review of Baig et al. (2016b). Some additional aspects and research results are interpreted towards an advanced insight for the application of adsorption. The surface characteristics such as topography, roughness, composition of substrates, and the chemical interactions of enzymes with the substrates are essential to develop understanding of the adsorption process to apply strategically.

\section{Constituents of various biomass materials}

Lignocellulosic materials are the common raw materials used for the production of biofuel. Cellulose, hemicellulose and lignin are the three main components present in lignocellulosic biomasses. Depending on their source, type, and kind of biomass the contribution of these components varies in their composition as given in Table 2.

Hardwood is obtained from alder, balsa, beech, hickory, mahogany, maple, oak, teak, and walnut trees while cedar, Douglas fir, juniper, pine, redwood, spruce, and yew provide softwood. Comprehension of the structures of the biomass components is important to appreciate the adsorption process; therefore, these are discussed here.

Cellulose is a polymer, its average molecular weight is approximately 100,000 . A single unit of glucose is shown in Fig. 1. The glucose units are in 6-membered rings having 5 carbons and one oxygen, called pyranoses. The glucose units are joined with the $\mathrm{C}-1$ of one pyranose ring and the $\mathrm{C}-4$ of the next ring by an acetal linkage.

In the glucose ring all the ' $\mathrm{H}$ ' atoms are in axial positions while the $\mathrm{OH}$ groups are in the equatorial positions. The equatorial positions of the hydroxyls groups develop hydrogen bonding with other groups. These hydrogen bonds hold the glucose chains together and form crystalline regions. The glucose chains are long and encompass numerous crystalline regions, with patches of disordered regions in between. The insolubility of cellulose in most of the solvents is due to the strong inter-chain hydrogen bonds in the crystalline areas. They also impart nonthermoplasticity to cellulose. At the disordered regions, the glucose chains are at a distance and are available to interact with other molecules. There are six conceivable structural arrangements of glucose chains to be held in

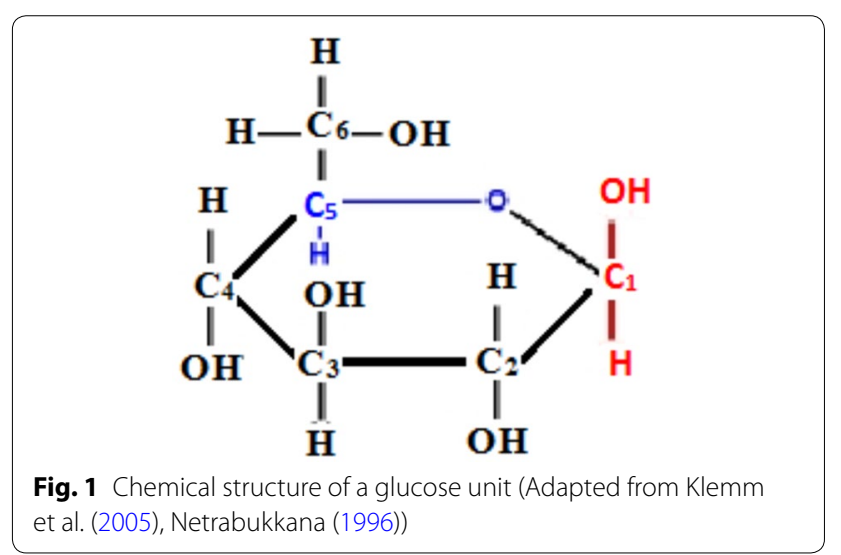

Table 2 Composition of various biomass substances in percentage

\begin{tabular}{|c|c|c|c|c|}
\hline Substrates & Cellulose & Hemicellulose & Lignin & References \\
\hline Hardwood & $40-50$ & $20-40$ & $15-30$ & Reyes-Rivera et al. (2015) \\
\hline Softwood & $45-50$ & $25-35$ & $20-25$ & Reyes-Rivera et al. (2015) \\
\hline Nut shells & $30-40$ & $25-30$ & $30-35$ & $\begin{array}{l}\text { Queirós et al. (2019), } \\
\text { Lourenco and Pereira } \\
(2018)\end{array}$ \\
\hline Corn cobs & $31-40$ & $30-40$ & $15-25$ & Rofiqah et al. (2019) \\
\hline Corn stovers & $30-41$ & $25-35$ & $15-25$ & Wang et al. (2019) \\
\hline Coastal Bermuda grass & $31-35$ & $26-30$ & $14-25$ & Canizo et al. (2014) \\
\hline Pineapple leaf & $25-30$ & $30-45$ & $15-20$ & Mansor et al. (2019) \\
\hline Cotton seed hairs & 80.95 & $5-20$ & 0.0 & Kumar et al. (2009) \\
\hline Wheat straw & $35-40$ & $20-30$ & $16-25$ & Isikgor and Becer (2015) \\
\hline Barley straw & $30-35$ & $20-30$ & $18-25$ & Lara-Serrano et al. (2019) \\
\hline News paper & $40-55$ & $25-40$ & $18-30$ & Kumar et al. (2009) \\
\hline Waste papers from chemical pulps & $30-80$ & $5-15$ & $1-20$ & loelovich (2014) \\
\hline Primary municipal wastewater solids & $8-15$ & NA & $24-29$ & Sun and Cheng (2002) \\
\hline Solid cattle manure & $2-5$ & $2-4$ & $2-6$ & Jung et al. (2015) \\
\hline
\end{tabular}


the elementary fibrils depending on the polymerization conditions (O'Sullivan 1997). Native cellulose is a heterogeneous mixture of not less than two structural arrangements (O'Sullivan 1997). The center of the elementary fibrils (micro-fibrils) of cellulose is very crystalline (Reza et al. 2019), and insoluble in water ( $\mathrm{Li}$ et al. 2018). The crystalline order of cellulose is hard to disrupt. By the action of enzymes, cellulose was broken down to cellobiose (a glucose dimer) which was further degraded to glucose. Reaction of cellulose may occur by disrupting the linkages holding the units together, or it may be any of the usual reactions of hydroxyl groups. In most reactions, the distribution of hydroxyl groups along the cellulose chain provides excellent binding (adsorption) sites for enzymes (Lindman et al. 2017).

Hemicellulose $\left(\mathrm{C}_{31} \mathrm{H}_{34} \mathrm{O}_{11}\right)_{\mathrm{n}}$ is a mixture of polysaccharides and its mean molecular weight is around 30,000. Hemicellulose is constituted with sugars (arabinose, glucose, mannose, and xylose) and uronic acids (methylglucuronic acid, and galacturonic acids). Chemical structure of hemicellulose contains $\mathrm{D}$-glucosidic units that are attached to each other by $\beta-1,3$ and $\beta-1,4$ linkages as shown in Fig. 2.

Hemicellulose is a branched polysaccharide which fastens to the surface of each cellulosic micro-fibril (Hopkins and Huner 2017). In biomass, cellulose is generally $40-50 \%$ and hemicellulose is $20-40 \%$ of the material by weight (Brigham et al. 1996; Pauly and Keegstra 2008; Saini et al. 2015; Zoghlami and Paes 2019). Hemicellulose has five-carbon sugars while cellulose has 6-carbon sugars.

Lignin is an amorphous compound, which has phenyl propanes [six-carbon ring attached with a threecarbon chain]. A polymeric form is shown in Fig. 3.
The methoxyl $\left(-\mathrm{OCH}_{3}\right)$ groups may be attached to the six member carbon rings. Three conformational isomers of lignin named as I, II and III are obtained due to attached 0, 1, 2 methoxyl groups, respectively. The conformation-I is present in grasses (Bykov 2008), conformation-II is in conifers wood and conformationIII is instituted in hardwoods. Lignin strengthens the cell structures by holding the fibers of polysaccharides together. Lignin contains methoxyl, hydroxyl (phenolic or alcoholic), carbonyl and carboxyl groups, in varying amounts, depending on origin and the lignin separation process applied (Gosselink et al. 2004). A brief availability of these function groups is given below:

Methoxyl groups: the methoxyl groups are 0.92 and 0.94 per one phenyl propane unit in softwoods and hardwoods, respectively (Bykov 2008; Davis et al. 2016; Lu et al. 2017).

Hydroxyl groups: there are three types of hydroxyl groups: (i) the straight chain hydroxyl groups are bound with $\Upsilon$-carbon; (ii) secondary hydroxyl groups are bound with $\alpha$-carbon, and phenolic groups are bound with 4th carbon $\mathrm{C}$ atom of aromatic rings. Lignins have almost 0.2 primary hydroxyl groups for each phenyl propane monomer, 0.84 secondary hydroxyl groups for each phenyl propane monomer, $0.30-0.35$ phenolic hydrox (yl groups for every phenyl propane monomer.

Carboxyl groups: there are $0.05 \mathrm{COOH}$-groups per 1 phenyl propane units of lignin. The carboxyl groups are generated through delignification due to oxidization of carbonyl, and hydroxyl groups. The alkaline lignin removal gives rise to carboxyl groups from 0.15 to 0.16 for each phenyl propane monomer. The increased concentration of carboxyl groups result in increased hydrophobicity of lignin material. The '-COOH' connects to

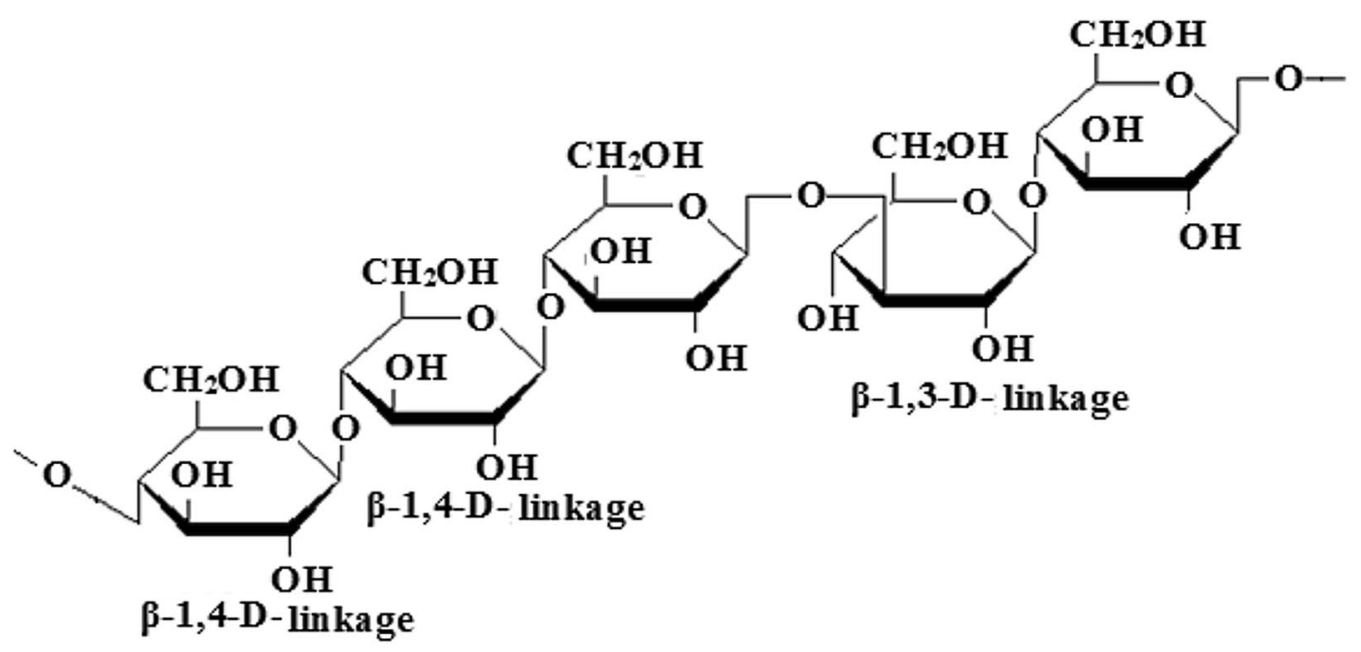

Fig. 2 A conformation of hemicellulose (Adapted from Klemm et al. (2005)) 


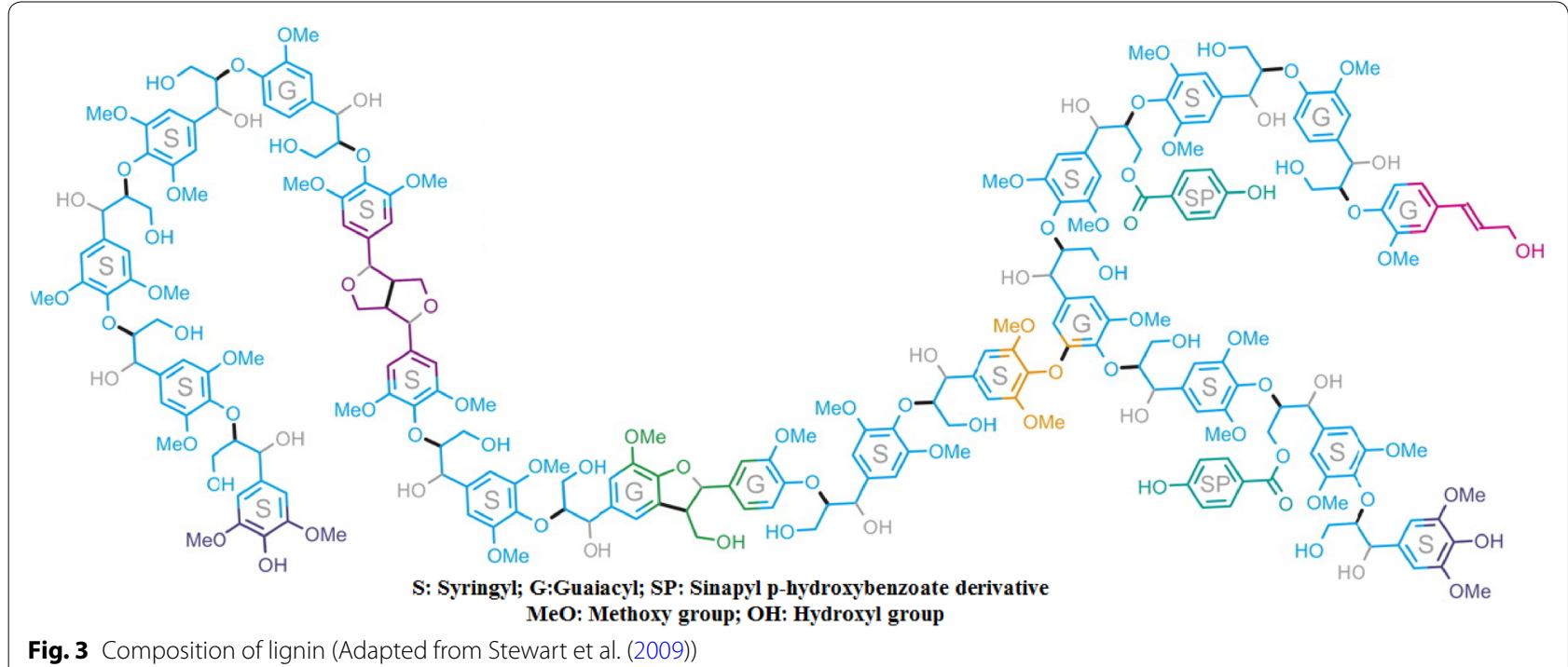

the functional groups of other molecules by hydrogen bonding.

Carbonyl groups: there are 0.21 carbonyl groups for each phenyl propane monomer. There are 4 carbonyl groups attached with $\Upsilon$-C atom in the form of aldehydes (0.04) and the rest of carbonyl groups, i.e., 0.17 are ketone. Hardwood lignin is easier to break down. Hardwood lignin can connect with other molecules through ether linkages more than softwood because the monomer in hardwood lignin is sinapyl alcohol. Because of the high reactivity of lignin towards enzymes, the presence of lignin is one of the major problems in bioethanol production (Katsimpouras et al. 2017).

\section{Physical structure of biomass}

From within the available biomass sources, the interest to use the grasses as energy crops has been increasing. The second largest family of monocotyledons is grasses (grass) having more than 700 genera and about 10,500 species including cereal crops such as wheat, barley, oats, rye and rice. The cereal crops are composed of nodes and internodes. Considering that wheat straw is the largest agricultural waste in Canada (37.52 million tons annually), it is discussed here. The wheat straw consists of internodes and nodes. Nodes are the hard points. The internodes are concentric rings, giving a void or cavity at the center. The outer layer (epidermis) is a dense layer of cellulose which has a silicon coating. Underneath the epidermis, there is a loose layer made of parenchyma and vascular bundle (Liu et al. 2005). Parenchyma are soft plant tissues made up of thin cells that form the greater part of leaves, stem pith, roots and fruit pulp. Vascular tissues are fluid-carrying vessels, e.g., sap-carrying vessels in plants. The vascular bundles are means of transportation in the wheat plants. The framework of the vascular bundles is made of cellulose. The primary wall is the outer layer containing a lignified thickening secondary wall, which contains cellulose (Liu et al. 2005). Figure 4 presents the outer surface of wheat straw.

The surface morphologies of wheat straw, indicate two subsets of fiber structure: (i) one with the fibrils of about 5- $\mu$ m diameter (part a), and (ii) the second with the diameter of about $10 \mu \mathrm{m}$ (part b), the part $\mathrm{c}$ and the part $d$ represent natural holes in surface for ventilation and metabolism (Baig 2008). Figure 5 shows vascular bundles with their longitudinal views. The annular or spiral form structure in vessel is quite bright. The other bright holes show protoxylem tracheid cells that have dense lignified thickening in the surrounding walls. The other part is lignin, which exist all around the cellulosic cells, between the cells and in vascular bundles. It provides bigger

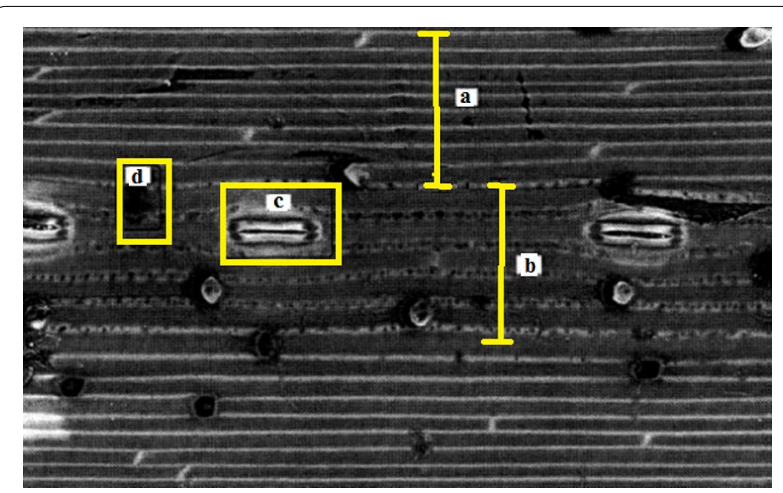

Fig. 4 Outer surface of wheat straw (Baig (2008)) 


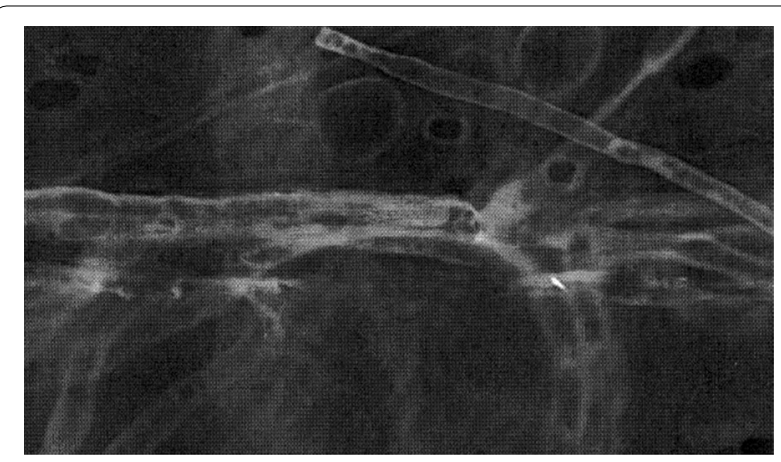

Fig. 5 Inner surface of wheat straw (Baig (2008))

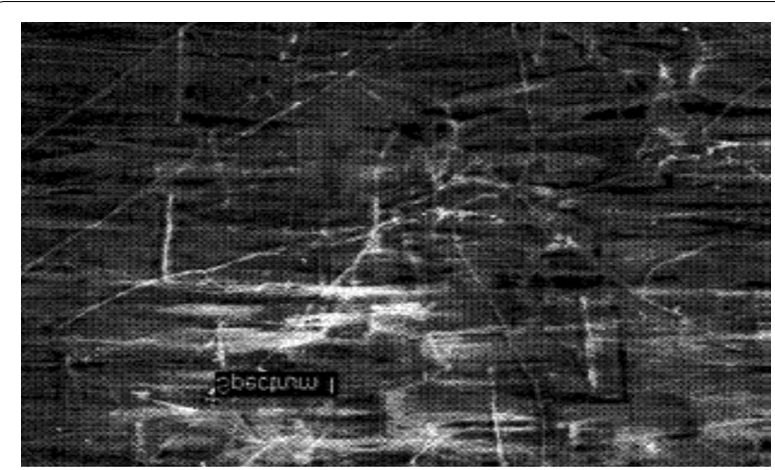

Fig. 6 Inner surface of wheat straw after soaking in distilled water (Baig (2008))

portion of sites for interaction due to its large number of phenolic groups, hydroxyl groups, methoxide groups and carboxylic groups (Baig 2008).

If enzymes are allowed to attach to the surface most probably the interaction with enzymes will make nonproductive bonding with enzymes. Therefore, the pretreatment of biomass to remove lignin is suggested. Figure 6 shows the appearance of wheat straw after soaking in distilled water and drying.
Enzymatic reactions normally occur in aqueous medium. Figure 6 shows how substrate fibers become more noticeable after soaking in aqueous medium, which helps in enzyme adsorption.

\section{Cellulases}

Cellulases are a mixture of enzymes which contain cellobiohydrolase I and II (CBHs), endoglucanase I and II (EGs) and $\beta$-glucosidase (though in small quantity). Fungi and bacteria produce extracellular cellulases, which degrade a number of wood and plants (Mandels and Weber 1969). A number of Trichoderma species such as T. reesei, T. viride, T. kongii and other fungal species such as Penicillium funiculosum, A. wentii produce extracellular cellulases. Cellulomonas and Clostridium thermocellum are bacteria that produce extracellular species able to degrade cellulose. Table 3 represents the main components of cellulases and their compositions in some available commercial enzyme complexes.

The modular structure of enzymes was deduced from the studies of T. reesei and Cellulomonas fimi. The modular structure has features: (i) carbohydrate-binding domain (CBD); (ii) catalytic domain (CD) or core; (iii) linker which join CBD and CD (Srisodusk et al. 1993). Some researchers (Hefford et al. 1992; Ramalingam et al. 1992; Wilson, 1992; Park et al. 1993) have confirmed this structure. The focus of the researches on cellulase adsorption onto crystalline cellulose was on the CBDcellulose relative actions; CBDs adsorb more to cellulosic surfaces (Palonen et al. 1999). The $\alpha$ - and $\beta$-structures of cellulose tend to have hydrophilic and hydrophobic interactions. From the crystalline regions of 36 parallel cellulose chains only $38 \%$ of surface area have hydrophobic tendency (Nimlos et al. 2007). The CBDs of family 1 and family 3 cellulases adsorbed on the hydrophobic regions cellulose produced from algae (Lehtio et al. 2003). The interaction of enzymes with carbohydrates occurred due to aromatic amino acid residues and the surface charges. The hydrogen bonding or van der Waals attractive forces may develop interactions between enzymes

Table 3 Main components of cellulase enzymes

\begin{tabular}{lllll}
\hline Enzyme & Lutzen et al. (1983) & Rosgaard et al. (2007) & Kang (2011) & $\begin{array}{l}\text { Hilden } \\
\text { and Johansson } \\
\text { (2004) }\end{array}$ \\
& Celluclast & Cellulases & Spezyme CP & NS 50013 \\
\hline Cel 7B, endoglucanase I & 10 & $5-10$ & 12 & 10 \\
Cel 5A, endoglucanase II & 10 & $1-10$ & 9 & 10 \\
Cel 7A, cellobiohydrolase I & 55 & $40-60$ & 50 & 60 \\
Cel 6A, cellobiohydrolase II & 10 & $12-20$ & 14 & 15 \\
B-Glucosidase & $1-2$ & N.D. & $<2$ & 2 \\
\hline
\end{tabular}


and carbohydrates (Rutledge and Wetmore, 2010; Wilson et al. 2014). There are contradicting results reported about the effect of $\mathrm{pH}$ on cellulase adsorption. The $\mathrm{pH}$ has a reticent influence on the adsorption of $T$. reesei Cel7A onto BMCC because the binding onto catalytic domain was remained unaffected by $\mathrm{pH}$ (Reinikainen et al. 1995). Some others reported that for high substrate concentration, substrate recognition is not an issue, hence, the CBDs adsorption becomes slightly influential (Le Costaouec et al. 2013; Varnai et al. 2010; Kwon et al. 2019).

\section{Interactions between enzyme and material surfaces at the molecular level}

Three types of interactions are involved in adsorption of enzyme onto lignin: (i) hydrophobic interactions (Ying et al. 2018; Tokunaga et al. 2019); (ii) electrostatic interactions (Nakagame et al. 2011; Scott et al. 2016), and (iii) hydrogen-bonding (Rahikainen et al. 2013; Liu et al. 2016). The CBDs of T. reesei cellulases, Cel7A and Cel5A were adsorbed onto lignin in significantly high amount (Yarbrough, et al. 2015; Liu et al. 2016) due to hydrophobic interaction. Some hydrophobic groups such as long chain carboxylic acid, phenolic and aliphatic hydroxyl groups were found in isolated lignin samples (Berlin et al. 2005). Lignin model compounds were deprotonated during adsorption process between $\mathrm{pH} 6.2$ to $\mathrm{pH} 11.3$ (Ragnar et al. 2000). Generally, the hydrolysis of lignocellulosic materials is carried out at $\mathrm{pH} 5$, when carboxylic acid groups present in lignin are deprotonated. Nakagame et al. (2011) reported that at pH 4.8 the isolated lignin showed a negative charge, and $T$. reesei enzymes (Cel6A and Cel5A) were positively charged, resulting in better adsorption. At elevated $\mathrm{pH}$ values the repulsive electrostatic forces between enzymes and lignin were increased, and hence adsorption onto ligneous substrate was decreased (Lou et al. 2013); enzyme reactions normally occur in aqueous medium. This figure shows how substrate fibers became more pronounced by soaking in aqueous medium, which helps in enzyme adsorption). This finding has a practical value from adsorption and desorption point of view (Baig 2016a).

The hydrophobic and electrostatic forces provide noncovalent interactions between enzymes and lignin surface while hydrogen bonding and dipolar interactions contribute a little (Kulkarni et al. 2015; Lundell 2018). The enzymatic cellulose degradation is hindered during prolonged reaction on biomass surfaces due to the inaccessibility of enzymes to the cellulose caused by the slow and regular accumulation of lignin (Djajadi et al. 2018). The lignin-rich components of biomass adsorbs enzymes more than non-lignin components, this type of adsorption is non-productive because it ceases the hydrolysis of feedstock (Nitsos et al. 2019; Yang et al. 2019). Adsorption onto lignin is non-productive, and hence disadvantageous for process economics.

The enzyme-cellulose substrate interactions at crystalline region of cellulose were vigorously studied. It was discovered that the enzymes adsorb onto cellulosic surfaces yeilding productive hydrolysis (Baig 2016a; Podgorbunskikh et al. 2019). The penetrating action of cellulose-binding modules of cellulases depends on their size, concentration, and binding equilibrium. There are 12 types of fundamental active amino acids residues present in enzymes. The surface amino acid residues on cellulases are charged residues. They have amide and hydroxyl functionalities. They probably interact with the $\mathrm{C} 1$ and $\mathrm{C} 4$ of the glucose unit to get adsorbed on the cellulose substrate. The adsorption connection is strengthened by the hydrogen bonding between cellulose and cellulase through hydroxyl groups on cellulose. To aid substrate binding, enzyme modification is another thought where protein stability at higher temperatures indicates a crucial role. Based on the structural information, a conceptual mechanism is given below which needs further research for validation.

\section{Adsorption mechanism of enzymes}

Enzymatic adsorption is initiated by movement of enzyme to the substrate surface in reaction solution under the influence of physical forces. The influencing physical forces are Brownian motion (Romanczuk et al. 2012; Lee et al. 2014; Yanagishima et al. 2014; Zhao and Mason 2018; Zhang and Hess 2019), van der Waals attraction forces (Hanefeld et al. 2009; Reis et al. 2018), and gravitational forces (Arca-Ramos et al. 2018). In addition to these, the effect of surface electrostatic charge (Feller et al. 2010; Filali et al. 2019) and hydrophobic interactions (Faccio 2018) is also present. Movement of enzymes is also controlled by concentration, diffusible or surface-bound chemical factors such as amino acids, sugars, and oligopeptides. These chemical factors regulate cellular adsorption components and prepare enzymesurface and cell-surface interactions (Hoarau et al. 2017).

Enzymes are transported from the bulk of the solution to the enzyme-substrate interface by the long-range attractive interactions. The long-range interactions between enzymes and surfaces are reciprocal forces depending on the distance in between and free energy available. The long-range interactions comes into play when the distance in greater than $50 \mathrm{~nm}$ (Katsikogianni and Missirli 2004; Qin and Buehler 2014). As the enzyme drifts closer to substrate surface, Van der Walls forces start acting within the distance range of 10-20 $\mathrm{nm}$ (Hermann et al. 2017). Short-range interfaces actions are influential at a 
distance of less than $5 \mathrm{~nm}$ between the active sites of enzymes and the substrate surface (Al-Haddad et al. 2013). This is a preliminary attachment which helps to develop interplay between the enzymes and substrate more. This first attachment of enzyme to surfaces is the preliminary adhesion, which makes the molecular or cellular phase of adhesion possible. Further to this towards adsorption, the main interactions are molecular-specific among surface-participating structures of enzymes and biomass substrate surfaces. This indicates a steadier adsorption of enzymes to the substrate surface. In brief, once the enzyme reaches the substrate surface, the adsorption is defined by chemical interactions. The chemical interactions may be due to attraction or repulsion of the functional groups taking part in the adsorption process. The interactions are led by the chemistries of the enzyme and substrate surfaces and the reaction medium, which is normally aqueous. Adsorption mechanism is depicted in a conceptual Fig. 7.

In Fig. 7, E enzymes are in the bulk of aqueous solution (adsorption medium). The gravitational forces and Brownian movement keep them moving as in part 'a'. They enzymes come in the range of long-rang e forces and they start moving towards substrate as in part 'b'. In the same time van der Walls forces start acting on the enzymes. Now enzymes are more directed toward substrates. They reach very close to the region where short-range attraction pulls them towards the substrate as in part 'c'. At this stage, enzymes are under the

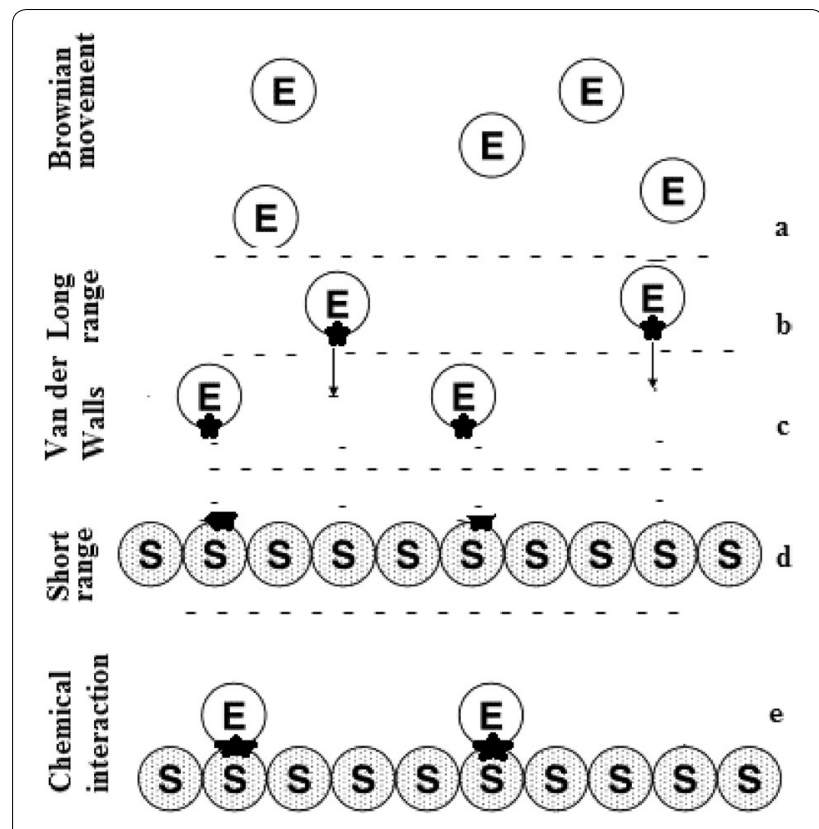

Fig. 7 Mechanism of adsorption of enzymes influence of all three forces (long range, van der Wall and short range) as the enzymes and substrate are very close to each other, the chemical interaction clamps enzymes with substrates as in part 'e'.

\section{Procedures to evaluate enzyme-substrate interactions}

There are simple, low-cost, easy systems to evaluate enzymatic adsorption onto lignocellulosic surfaces (Tamer, et al. 2016; Zadrta et al. 2018; Reis et al. 2018). The procedure adapted may be as follows: a ready-to-use surface is allowed to come across with the enzymes suspension for a pre-established time interval. Subsequently, the nonadsorbed enzymes are removed by centrifugation and the adsorbed enzymes on the surface are calculated. The non-adsorbed or softly adsorbed enzymes are separated by centrifugation and this step may be used to evaluate an overall strength of adhesion (Baig 2016). Various techniques can be used to examine the adsorbed enzyme:

1. Microscopy to determine the morphology of adsorbed enzymes and calculate the numbers. Light microscopy used to examine the specimen must properly illuminate to view the enlarged image of specimen.

2. Scanning electron microscope (SEM). SEM uses a beam of electron to give details of the examined surface. The magnification range is around $2 \times$ to $250,000 \times$

3. Scanning confocal microscopy. It is a laser scanning technique which develops pixel-by-pixel image by assembling the emitted photons from the fluorophores of the sample.

4. Atomic force microscopy. It is a scanning probe microscopy. It measures local properties of a sample such as height, friction and magnetism. It can perform in vacuum, gas and liquid environments.

5. Radiolabelling. 5-Cyano-2,3-ditolyl tetrazolium chloride.

6. Direct and indirect methods.

a. Spectrophotometry.

b. Coulter counter apparatus can be used to count and size enzymes.

\section{Environment}

The adsorption of enzymes onto biomass substrates depends on a number of factors such as associated flow conditions, temperature of medium, contact time of enzymes (incubation time), concentration of enzymes, concentration of substrate, the presence of contaminants. Flow conditions strongly influence the adsorption 
process by governing the number of attached enzymes (Bekard et al. 2011; Lippok et al. 2016). It is commonly conceived that lower shear rates or low agitation give higher adsorption. As soon as enzymes were exposed to an adsorbent material, the enzymes develop interactions due their surface features. The binding interactions became ineffective with increases in shear rates from 50 to $300 \mathrm{~s}^{-1}$

\section{Shear forces}

The shear forces are created by agitation, shaking or mixing. Therefore, the flow conditions for process should be selected carefully. Table 4 shows that at $100 \mathrm{rpm}$ the cellulose in spruce wood was $20 \%$ converted to glucose. While keeping all other conditions (substrate loading, enzymes loading, temperature, contact time, etc.) constant and rpm were increased to 300 , the conversion was increased to $31 \%$, a further increase in rpm to 600 resulted in $37 \%$ conversion. Varnai et al. (2011) has reported similar results on adsorption of cellulases enzymes. Shaking, agitation, varying rpm all have an influence on the number of adsorbed enzymes, i.e., increased (Thomas et al. 2010; Palmqvist et al. 2011; Kadic et al. 2014). It is important to remind that enzymes those are adsorbed will only convert the material to product and those who are not adsorb will not be able to cause any conversion. Therefore, conversion (hydrolysis) is taken as an indirect measure of adsorption.

While keeping all other factors constant the substrate loading was decreased to $7 \%$, there was almost no change in adsorption on enzymes to the substrate surface. Similar results are available in literature when there was no change in adsorption (Kadic et al. 2014; Ingesson et al. 2001) or a little change in adsorption was observed due to change in flow conditions (Kadic et al. 2014; Bhagia et al. 2019). The cellulases and biochar obtained by lowtemperature hydrothermal carbonization (LTHTC) of biomass were intensively shaken on a shaker at $300 \mathrm{rpm}$ and $500 \mathrm{rpm}$ for $7 \mathrm{~h}$ for adsorption. Higher adsorption efficiency and residual enzyme activity were achieved when the carrier and the enzyme were shaken at lower agitation speed. Higher agitation speeds obviously shortened the time of contact between the enzyme and the carrier; therefore, adsorption efficiency and residual enzyme activity decreased (Mercon et al. 1997). The literature survey led to the following hypotheses: (i) layers of enzymes were formed which hinder the access of enzymes to the substrate; (ii) the enzyme configuration has been modified by vicinity. It is commonly believed that advanced shear rates gives better disengagement forces that decrease the number of adsorbed enzymes (Katsikogianni and Missirlis 2004) with decrease in boundary layer and thinned the biofilm (Qureshi et al. 2005).

Once in contact with substrate, the enzymes develop a relationship with the substrate surface. To further explain it consider the adsorption of a ligand molecule onto a receptor protein, the number of adhesive bonds formed would depend on the charge densities of the ligand and the receptor (Robert et al. 2011; Ding et al. 2019). A specific force is always required to disintegrate a bond. The shear stress required to separate enzymes from the substrate can be estimated by the amount of bonds linking enzymes and surface (Engler et al. 2009: Kim et al. 2016). The adsorption of cells, S. aureus to collagen (proteins present in skin) was increased with increase in the shear rates between $50 \mathrm{~s}^{-1}$ up to $300 \mathrm{~s}^{-1}$ and dropped when shear rates were increased above $500 \mathrm{~s}^{-1}$ (Mohamed et al. 2000; Ribeiro et al. 2012). During adsorption, the quantity of bonds of the attached enzyme and substrate can be

Table 4 Mixing to facilitate enzymatic adsorption

\begin{tabular}{llll}
\hline Substrate & Enzyme & Mixing & References \\
\hline Spruce 13\% loading & Cellulases & $100 \mathrm{rpm}, 48 \mathrm{~h}, 20 \%$ conversion & Kadic et al. (2014) \\
Spruce 13\% loading & Cellulases & $300 \mathrm{rpm}, 48 \mathrm{~h}, 31 \%$ conversion & Kadic et al. (2014) \\
Spruce 13\% loading & Cellulases & $600 \mathrm{rpm}, 48 \mathrm{~h}, 37 \%$ conversion & Kadic et al. (2014) \\
Giant reed, 13\% loading & Cellulases & $100 \mathrm{rpm}, 48 \mathrm{~h}, 43 \%$ conversion & Kadic et al. (2014) \\
Giant reed 13\% loading & Cellulases & $300 \mathrm{rpm}, 48 \mathrm{~h}, 53 \%$ conversion & Kadic et al. (2014) \\
Spruce 7\% loading & Cellulases & $100 \mathrm{rpm}, 48 \mathrm{~h}, 31 \%$ conversion & Kadic et al. (2014) \\
Spruce 7\% loading & Cellulases & $100 \mathrm{rpm}, 48 \mathrm{~h}, 32 \%$ conversion & Kadic et al. (2014) \\
Giant reed 7\% loading & Cellulases & $300 \mathrm{rpm}, 48 \mathrm{~h}, 56 \%$ conversion & Kadic et al. (2014) \\
Giant reed 7\% loading & Cellulases & $300 \mathrm{rpm}, 48 \mathrm{~h}, 56 \%$ conversion & Kadic et al. (2014) \\
Cellulose 7.5\% loading & Cellulases & $25 \mathrm{rpm}, 72 \mathrm{~h}, 61.3 \%$ conversion & Ingesson et al. (2001) \\
Cellulose 7.5\% loading & Cellulases & $150 \mathrm{rpm}, 72 \mathrm{~h}, 68.4 \%$ conversion & Ingesson et al. (2001) \\
Cellulose 2.5\% loading & Cellulases & $25 \mathrm{rpm}, 72 \mathrm{~h}, 78.8 \%$ conversion & Ingesson et al. (2001) \\
Cellulose 2.5\% loading & Cellulases & $150 \mathrm{rpm}, 72 \mathrm{~h}, 82.2 \%$ conversion & Ingesson et al. (2001) \\
\hline
\end{tabular}


changed (rise or decline). The enzyme will detach as the number of bonds decreased below a critical value (Sridhar et al. 2018). Walstra (2001) studied the adsorption of an enzyme of 40 kilodalton $(\mathrm{kDa})$ molecular weight with the surface coverage of $2 \mathrm{mg} \mathrm{m}^{-2}$. The sheer stress of 1 Pa provided deformation energy of about $10^{-25} \mathrm{~J}$ for each molecule while a shear stress of about $5 \times 10^{5} \mathrm{~Pa}$ is required to denature an enzyme (Bekard et al. 2011). As the working medium is water, which means a 1000 times higher shear rate of $5 \times 10^{50}$ (i.e., $5 \times 10^{8} \mathrm{~Pa} \mathrm{~s}^{-1}$ ) would be required to denature a small globular enzyme. Jaspe and Hagen (2006) predicted that a shear stress of $10^{7} \mathrm{~s}^{-1}$ could unfold cytochrome enzyme having free energy $42 \mathrm{~kJ} \mathrm{~mol}^{-1}$. Walstra (2001) used another technique (surface tension) to estimate attraction at air-liquid interface and found that the free energies applied were about $400 \mathrm{~kJ} \mathrm{~mol}^{-1}$ to the adsorbed enzyme, which is $10^{-18} \mathrm{~J}$ for every molecule. Therefore, it can be expected that enzymes may unfold at interfaces under high shear stresses. The force required to detach enzymes increases as the contact time reached the largest value which indicates that the supplementary interconnections are developed gradually after the first temporary attachment of an enzyme to the substrate.

\section{Temperature}

The reported results about the influence of temperature on the adsorption of cellulases are controversial. Some of the investigators proposed that the adsorption of cellulases onto the biomass material was an exothermic process which was controlled by enthalpy. It was also observed that the concentration of cellulases adsorbed was reduced as the temperature was augmented (Medve et al. 1994; Kim et al. 2000; Ooshima et al. 1983). Conversely, Hoshino et al. (1992) and Creagh et al. (1996) proposed that the adsorption of enzymes onto MCC was an endothermic reaction and it was controlled by entropy, means increased with temperature. Tu et al. (2009) investigated reaction of cellulases on a soft wood (lodgepole pine, Pinus contorta). The soft wood is composed of $45-50 \%$ cellulose, $30-35 \%$ hemicellulose, 20-25\%; lignin, and $4-5 \%$ extractives). At $4{ }^{\circ} \mathrm{C}$, $25{ }^{\circ} \mathrm{C}$ and $45{ }^{\circ} \mathrm{C}$. The lignin obtained by steam exploding lodgepole pine (L-SELP), and lignin obtained by ethanol-pretreated lodgepole pine (L-EPLP) was used for the adsorption experiments. A maximum amount of cellulase was adsorbed onto lignin at $45{ }^{\circ} \mathrm{C}$ than at 4 and $25{ }^{\circ} \mathrm{C}$, implying that the adsorption of cellulases onto L-SELP and L-EPLP was an endothermic process (Tu et al. 2009; Zheng et al. 2013a). This is true for the adsorption of cellulases onto lignin, because there exists a hydrophobic interplay between lignin and enzymes ( $\mathrm{Tu}$ et al. 2007). The driving force for adsorption under the influence of hydrophobic interactions is entropy (Tu et al. 2009; Wang et al. 2010). The adsorption process, which is entropy-driven, was established by experimental data obtained from titration micro-calorimetry (Creagh et al. 1996). It means that lignin adsorbs more cellulases and with increase in temperature the adsorption on lignin increased. These results also implied that delignification

Table 5 Effect of temperature on adsorption

\begin{tabular}{|c|c|c|c|c|}
\hline Adsorbate & Adsorbent & Temperature studied & Effect & References \\
\hline BsEXLX1 & Cellulose & $25^{\circ} \mathrm{C}, 45^{\circ} \mathrm{C}$ only & Decreased with increasing temp & Duan et al. (2018) \\
\hline Cellulase & Wheat straw & $25-70{ }^{\circ} \mathrm{C}$ & Increased till $50^{\circ} \mathrm{C}$ & Baig et al. $(2016 c$, d) \\
\hline Cellulase ATCC 26921 & Treated, spent coffee residues & $30-50^{\circ} \mathrm{C}$ & Increased till $40^{\circ} \mathrm{C}$ & Buntic et al. (2016) \\
\hline Cellulases & $\mathrm{H}_{2} \mathrm{SO}_{4}$ treated corncob & $4-50^{\circ} \mathrm{C}$ & Increased with increasing temp & Du et al. (2014) \\
\hline EGs Aspergillus fumigatus & $\begin{array}{l}\mathrm{NaOH} \text { treated bagasse, corn husk, } \\
\text { coconut coir, rice bran, rice } \\
\text { straw, saw dust, wheat bran, } \\
\text { wheat straw }\end{array}$ & $4-40^{\circ} \mathrm{C}$ & Decreased with increasing temp & Das et al. (2013) \\
\hline Accellerase 1000 & Commercial pure cellulose & $4^{\circ} \mathrm{C}, 50^{\circ} \mathrm{C}$ only & Decreased with increasing temp & Zheng et al. (2013b) \\
\hline Celluclast & $\mathrm{AL}, \mathrm{HL}, \mathrm{OL}, \mathrm{LS}, \mathrm{SL}, \mathrm{PL}, \mathrm{BWX}, \mathrm{GM}$, & $4,45^{\circ} \mathrm{C}$ only & Increased with increasing temp & Pareek et al. (2013) \\
\hline Accellerase 1000 & ACS-L, SECS-L, SERS-L & $4{ }^{\circ} \mathrm{C}, 50^{\circ} \mathrm{C}$ only & Increased with increasing temp & Zheng et al. (2013a) \\
\hline Purified endoglucanase (CMCase) & Commercial pure cellulose & $10-40^{\circ} \mathrm{C}$ & Decreased with increasing temp & Das et al. (2012) \\
\hline $\begin{array}{l}\text { Penicillium notatum NCIM } \\
\text { NO-923 }\end{array}$ & Commercial pure cellulose & $10-40^{\circ} \mathrm{C}$ & Decreased with increasing temp & Das et al. (2012) \\
\hline $\mathrm{CBHs}, \mathrm{EGs} /$ & Steam exploded spruce lignin & $4,30^{\circ} \mathrm{C}$ only & Almost the same adsorption & Piccolo et al. (2010) \\
\hline $\mathrm{CBHs}, \mathrm{EGs} /$ & Commercial pure cellulose & $4,30^{\circ} \mathrm{C}$ only & Almost the same adsorption & Piccolo et al. (2010) \\
\hline $\mathrm{CBHs}, \mathrm{EGs} /$ & Pretreated WS & $4,30^{\circ} \mathrm{C}$ only & Almost the same adsorption & Piccolo et al. (2010) \\
\hline Aspergillus niger cellulase & Activated carbon powder & $20-60^{\circ} \mathrm{C}$ & Increased with increase in temp & Daoud et al. (2010) \\
\hline
\end{tabular}

BsEXLX1: Bacillus subtilis expansion; CMCase: carboxy methyl cellulase 
of lignocellulosic substrates for cellulases desorption was necessary. Through a literature survey (Table 5) it was observed that effect of temperature is a complex phenomenon because on the one hand it influences adsorption, desorption and on the other hand, it affects activity of the cellulases.

Other activities of endoglucanase and exoglucanase enzymes after adsorption reported that $29 \%$ of the initially added cellulases enzymes were free in solution at $45{ }^{\circ} \mathrm{C}$, while $9 \%$ of cellulases were free at $55{ }^{\circ} \mathrm{C}$, after $4 \mathrm{~h}$ of contact time. Additionally, enzymes were strongly bound on spruce (enzymatically purified) lignin at high temperature, which presented a sudden decrease in the concentration of adsorbed enzyme at $55^{\circ} \mathrm{C}$ than that of at $45^{\circ} \mathrm{C}$ (Rahikainen et al. 2013). The increase in adsorption of enzymes onto lignin and increased denaturation of enzymes were due to negative effect of temperature on the adsorption (Rahikainen et al. 2013; Borjesson et al. 2007; Viikari et al. 2007). Bonomo et al. (2006) investigated adsorption of bovine serum albumin (BSA) and $\beta$-lactoglobulin $(\beta-\mathrm{lg})$ onto a hydrophobic adsorbent (Streamline Phenyl, packed in a column HR 5/5) to evaluate stability of enzymes in the temperature range of $10-40{ }^{\circ} \mathrm{C}$ and suggested that over $30^{\circ} \mathrm{C}$ a great conformational change occurs. Cellulases from T. reesei (Celluclast $1.5 \mathrm{~L}$, Spezyme CP), cellulases from Penicillium sp. (MSUBC) onto CEL from SELP and EPLP showed that the activity of Celluclast $1.5 \mathrm{~L}$ increased from 25 to $45^{\circ} \mathrm{C}$ and enzymes were denatured from 55 to $75^{\circ} \mathrm{C}(\mathrm{Tu}$ et al. 2009). Baig (2016) observed a decrease in desorption of enzymes, and those desorbed were not active any more. It was concluded that cellulase enzymes degraded on at temperature 60 and above. Degradation of enzymes means conformational changes and loss of capability to perform their function (activity). It is important to know what is the focus of study whether the researcher wants to determine adsorption only or researcher needs to know about biodegradability of the biomaterial which includes the processes of adsorption, hydrolysis and desorption.

\section{Time of contact}

The adsorption profile of cellulases onto microcrystalline cellulose (Avicel) was established by Singh et al. (1991) who reported that most of the enzymes were adsorbed onto Avicel and pulp within the first $10 \mathrm{~min}$ of contact at $30{ }^{\circ} \mathrm{C}$. Steiner et al. (1988) reported that $50 \%$ of the maximally adsorbed enzyme was adsorbed within 1-2 min of contact with microcrystalline cellulose; however, adsorption equilibrium was established less than $30 \mathrm{~min}$. Pulp exhibited higher enzyme adsorption than Avicel. The greater part of cellulase (around 18\%) was adsorbed onto xylan substrate within 10-20 min of contact. Jager et al. (2010) reported that cellulase adsorption on $\alpha$-cellulose was rapid, cellobiohydrolase $\mathrm{CBH}$ I reached equilibrium in $20 \mathrm{~min}$ and endoglucanase EG I in 30 min. Pareek et al. (2013) adsorbed cellulases on spruce lignin (SP) and black cotton wood lignin (BCWL) and found that around $60 \%$ of the enzymes were adsorbed within first $30 \mathrm{~min}$ of contact time, while adsorption took more than $2 \mathrm{~h}$ to reach to the same value for BCWL. To establish a dynamic

Table 6 Adsorption equilibrium for various adsorption systems

\begin{tabular}{|c|c|c|c|}
\hline Enzyme & Substrate & Equilibrium time & References \\
\hline Cellulase & Lignin from corn stover & $60 \min 4{ }^{\circ} \mathrm{C}$ & Yuan et al. (2018) \\
\hline $\mathrm{CBH} I \mathrm{EG} \mid$ & Cellulose & $40 \min 45^{\circ} \mathrm{C}$ & Jager et al. (2010) \\
\hline Cellulases & Cellulose (Avicel PH 101) & $20 \min 25^{\circ} \mathrm{C}$ & Baig et al. (2016e) \\
\hline Cellulases & Lignin (Protobind) & $40 \min 25^{\circ} \mathrm{C}$ & Baig et al. (2016e) \\
\hline Cellulase & Avicel & $10 \min 4{ }^{\circ} \mathrm{C}, 50^{\circ} \mathrm{C}$ & Machado et al. (2015) \\
\hline Cellulase & Organosolv bagasse, lignin & $120 \min 4{ }^{\circ} \mathrm{C}, 50^{\circ} \mathrm{C}$ & Machado et al. (2015) \\
\hline$\beta$-Glucosidase & Cellulose (Avicel), hydrothermal bagasse & No adsorption $4{ }^{\circ} \mathrm{C}, 50^{\circ} \mathrm{C}$ & Machado et al. (2015) \\
\hline Fusarium oxysporum cellulase & Egg white matrix & $80 \min 20^{\circ} \mathrm{C}, 27^{\circ} \mathrm{C}, 37^{\circ} \mathrm{C}$ & Singh and Kaur (2014) \\
\hline Cellulase CG220 & Pretreated corncob & $90 \min 10^{\circ} \mathrm{C}, 20^{\circ} \mathrm{C}, 30^{\circ} \mathrm{C}$ & Du et al. (2014) \\
\hline Lyophilized cellulase & Cellulose & $60 \min 25^{\circ} \mathrm{C}$ & Maurer et al. (2012) \\
\hline Aspergillus niger cellulase & Activated carbon & $40 \min 20^{\circ} \mathrm{C}, 50^{\circ} \mathrm{C}$ & Daoud et al. (2010) \\
\hline $\mathrm{CBH}$ I, $\mathrm{CBH} \|$ & Microcrystalline cellulose & $60 \mathrm{~min}$ & Kim et al. (2000) \\
\hline Cellulases QM 9414 & Microcrystalline cellulose & $15 \min 10^{\circ} \mathrm{C}, 20^{\circ} \mathrm{C}, 30^{\circ} \mathrm{C}$ & Sethi et al. (1998) \\
\hline $\mathrm{CBH} \mathrm{I}, \mathrm{CBH} \|$ & Microcrystalline cellulose & $90 \min 4{ }^{\circ} \mathrm{C}, 25^{\circ} \mathrm{C}, 40^{\circ} \mathrm{C}$ & Medve et al. (1994) \\
\hline Talaromyces emersonii cellulases & Cellulose & $15 \min 5^{\circ} \mathrm{C}$ & Beldman et al. (1987) \\
\hline Talaromyces emersonii cellulases & Cellulose & $\begin{array}{l}15 \min 50^{\circ} \mathrm{C} \text {, more adsorption than } \\
5^{\circ} \mathrm{C}\end{array}$ & Beldman et al. (1987) \\
\hline
\end{tabular}


adsorption equilibrium, a sufficient time of incubation is required. Table 6 shows that adsorption equilibrium time varies with the type of enzymes, type of biomass substrates and the environmental conditions.

Most of researchers investigated adsorption of metal ions, dyes and enzymes on various lignocellulosic substrates at varying temperatures. Their findings were that by increasing temperature, equilibrium constant value was increased, but the time to reach equilibrium remains the same (Medve et al. 1994; Sethi et al. 1998; Kim et al. 2000; Daoud et al. 2010; Zheng et al. 2013a; 2014; Du et al. 2014; Sukumaran et al. 2017; Houston et al. 2019). Some of the researchers have shown adsorption plot at one temperature and used the same equilibrium time for all other temperatures of studies (Sethi et al. 1998; Houston et al. 2019). Baig (2016a) submitted his observations about adsorption by stating at the start, adsorption progress with the time when the enzymes are placed with the substrate of interest. As the contact time increased, the cellulases adsorbed more and adsorption achieved its maximum almost at $20 \mathrm{~min}$ after of contact time, then it seemed to level off, i.e., adsorption equilibrium is achieved. Therefore, the time used for adsorption studies was set to $30 \mathrm{~min}$. In the study of enzymatic adsorption/ hydrolysis, it was a tradition that the enzyme contents in the supernatant were measured as the free cellulases $\left[\mathrm{P}_{\mathrm{f}}\right]$ and the adsorbed cellulases $\left[\mathrm{P}_{\mathrm{a}}\right]$ were calculated from the difference between the initial cellulases concentration and the free cellulases (Stuart and Ristroph 1984; Tu et al.
2009) which was carried out. In this set of experiments, it was found that on increasing the initial cellulases concentration $\left[P_{0}\right]$ from 100 to $183 \mu \mathrm{g} \mathrm{mL}{ }^{-1}$, adsorption increased from 68.45 to $109.3 \mu \mathrm{g} \mathrm{mL} \mathrm{m}^{-1}$ for $100 \mathrm{mg}$ of Avicel. Further increase in $\left[P_{0}\right]$ from 183 to $262 \mu \mathrm{g} \mathrm{mL}^{-1}$ cannot bring any significant change in $\left[P_{\mathrm{a}}\right]$ (i.e., from 109.3 to $116.2 \mu \mathrm{g} \mathrm{mL}^{-1}$ ). The value of maximum cellulases adsorbed was similar to that determined by other researches on various lignocellulosic substrates (Singh et al. 1991; Nidetzky and Steiner 1993). The supernatant obtained after adsorption of $183 \mu \mathrm{g} \mathrm{mL} \mathrm{m}^{-1}$, at $25^{\circ} \mathrm{C}, \mathrm{pH}$ 5 for a contact time of $60 \mathrm{~min}$ showed that no reducing sugars were formed. So, no noticeable hydrolysis took place during any of the adsorption experiments. Microcrystalline cellulase (Avicel PH-101) was 7\% hydrolyzed in $24 \mathrm{~h}$ and $72 \%$ of it was hydrolyzed within initial $5 \mathrm{~h}$ of contact (Andersen et al. 2008). Therefore, for the study of adsorption only or the study adsorption for hydrolysis, contact time is an important factor. Contact time may vary depending on the enzyme-substrate system and the environmental condition applied to the enzyme-substrate system.

\section{Concentration}

Before reaching the optimum value, the increase in enzyme concentration increase the adsorption, for a fixed amount of substrate. Some enzyme and substrate pairs are given in Table 7 with the effect of increasing substrate concentration. The agricultural residues (corn stover,

Table 7 Effect of change in substrate concentration on adsorption process

\begin{tabular}{|c|c|c|c|}
\hline Enzymes & Substrates & Comments & References \\
\hline Cellic CTec2 & Sorghum & Increased with increase in conc & Nghiem and Toht (2019) \\
\hline T. longibrachiatum LC-M4 & Sorghum & Increased with increase in conc & Dong et al. (2019) \\
\hline Cellulase T. reesei & Cellulose & Increased with increase in conc & Tervasmäki et al. (2017) \\
\hline $\begin{array}{l}\text { Celluclast } 1.5 \text { L, Cellic CTec2 and } \\
\text { Cellic CTec3 }\end{array}$ & $\begin{array}{l}\mathrm{SO}_{2} \text {-pretreated poplar and lodgepole } \\
\text { pine }\end{array}$ & Increased with increase in conc & Mok (2015) \\
\hline Cellulase T. reesei & Cellulose (Avicel PH 101) & Increased with increase in conc & Baig et al. (2016e) \\
\hline Cellulase T. reesei & Lignin (Protobind) & Increased with increase in conc & Baig et al. (2016e) \\
\hline Accellerase 1000 T. reesei & $\begin{array}{l}\text { Cellulose } \\
\text { APC } \\
\text { SPC } \\
\text { SPR }\end{array}$ & Increased with increase in conc & Zheng et al. (2013a) \\
\hline $\mathrm{CBH} I \mathrm{EG} 2$ & Cellulose & Increased with increase in conc & Shi et al. (2016) \\
\hline Spezyme-CP & Cellulose & Increased with increase in conc & Kumar and Wyman (2008) \\
\hline GC-220 & Cellulose & Increased with increase in conc & Kumar and Wyman (2008) \\
\hline Cellulase & Avicel & Decreased with increase in conc & Eckard et al. (2013) \\
\hline Cellulases & Pretreated forest wood & Increased with increase in conc & Matsakas et al. (2018) \\
\hline Celluclast $1.5 \mathrm{~L}$ T. reesei & Corn stover and corn fiber & Increased with increase in conc & Arantes and Saddler (2011) \\
\hline Cellic CTec 2 & High $\mathrm{Crl}$ cellulose & Increased with increase in conc & Li et al. (2018) \\
\hline
\end{tabular}

APC: dilute acid-pretreated corn stover; SPC: steam explosion-pretreated corn stover; Crl: Crystallinity Index SPR: steam explosion pretreated rice straw; Cellic CTec2: cellulase and hemicellulase complex; T. reesei: Trichoderma reesei; T. longibrachiatum: Trichoderma longibrachiatum 
corn fiber, rice husk, wheat straw, etc.) needs considerably lower protein loadings to achieve optimum adsorption than the forestry residues (poplar, Douglas fir and lodgepole pine). The adsorption efficiency depends in the resource and chemical constitution of a feedstock, and the employed pretreatment technologies. Pretreatment technologies are important, because efficiency of enzymatic adsorption depends on the accessibility of the enzymes to the cellulosic substrate.

Baig (2016a) conducted a vigorous study on the adsorption of cellulases on cellulose (Avicel PH 101) at room temperature, at various contact times, for eight initial cellulases concentration and found that adsorption increased with the increase in enzyme concentration before reaching an optimum value. Further increase in enzyme concentration makes no difference; in fact, the time to reach adsorption equilibrium was increased. In case adsorption is being conducted for biofuel production, the rate-limiting step during hydrolysis is not the catalytic cleavage of the cellulose chains, rather the accessibility of the enzymes to the cellulose. In case of biomedical implants an optimum adsorption of proteins is acceptable to develop protein layers for binding between implant and body.

Adsorption on lignin takes longer than that of cellulose. One cause of the delayed interaction could be the repulsion between amino acids tyrosine and histamine from cellulases and the carbonyl from lignin may allow cellulases to rearrange in order to adsorb onto lignin. Therefore, involvement of a number of positive and negative functional groups makes adsorption on lignin complex phenomena take a longer time. Detection of reducing sugars from the contact of cellulases with Protobind 1000 was not evaluated since lignin does not contain any polymeric sugars.

\section{Discussion}

Enzymes are very useful catalysts for degradation of biomass through adsorption, hydrolysis reactions. Like all catalysts, enzymes increase the speed of reactions by providing an alternative reaction pathway of lower activation energy. Enzymes take part in the reaction and provide an alternative reaction pathway. Enzymes are highly selective; therefore, catalyze specific reactions by altering the rate of adsorption, not the position of the adsorption equilibrium. This specificity requires the right selection of enzymes for substrates of given lignocellulosic materials under the provided environmental conditions, because every enzyme has certain advantages and disadvantages over the adsorption to a substrate. The universally used enzymes are cellulases for cellulose, xylenes, xylosidase and esterase for hemicellulose, and heme peroxidases, manganese peroxidase and laccases for degradation of lignin. These enzymes adsorbed well on lignocellulosic biomass, which is a first stage for the production of biofuel. The cost of enzymes and the ease of distribution of enzymes over the accessible substrate area are important steps in the adsorption process. A very careful monitoring of enzymatic adsorption literature leads to a point that the adsorption is faster at the beginning and slower in the later stages. Imagine the adsorption process. When enzymes are adsorbed on the surface, after adsorption they hydrolysed the surface as the result three things happen: (i) product is formed, (ii) enzyme is freed for another adsorption, (iii) substrate offers more surface area that it was in the start of adsorption. It gives rise to questions such as, is it because enzymes are not productive anymore? Useful surface area is exhausted. Alternatively, the surface area is not a relevant parameter for adsorption and hence for hydrolysis. The probable reason is that the remaining crystalline cellulose has a structure that is more compact and it appears to be the influencing aspects, which finally regulate the efficiency of adsorption (Khodaverdi et al. 2012). In conducting tests for the evaluation of the adsorption process where amount of the enzymes adsorbed and that remaining in the solution should be precisely measured. The probability of a range of adsorption for each enzyme could be minimized by giving sufficient time to develop an equilibrium between adsorption and desorption process as detailed in the section 'Contact time'. In all the methodologies used, the postulations of the principal mechanisms of the enzymes moving toward the substrate surface, the adsorption kinetics, and the development of central site for adsorption, the assumption for the intermolecular linkage, and the number of particular receptors for the interacting ligands add to the nature of such researches. The accessibility of enzymes to cellulose and hemicellulose substrates is around 90\% through the inside pores rather than the outer surface (Dutta and Chakraborty 2016).

Adsorption onto the outer surface has small contribution in the overall adsorption. Sometime lignocellulosic materials are subjected to pre-treatments. The pre-treatments improve a number of features of substrate, which help adsorption. Pretreatment produce improved solid surfaces that can enhance adsorption and hence produce more sugars during enzyme hydrolysis. It forestalls the degradation of sugars during the process. It reduces or ends the formation of inhibitors for succeeding fermentation process. Pretreatment makes recovery of lignin easy, which can be converted into value added by-products, and minimizes heat and power requirements to be cost effective. The vast array of biomass types is given in the section 'Constituents of various biomass materials' which excludes the possibility of applying one pretreatment 
methodology or all various lignocellulosic materials. From the cost point of view, Eggeman and Erlander (2005) stated that one type of material might not be a feasible process for another lignocellulosic biomass type. Enzymatic adsorption is a type of heterogeneous catalysis. In catalysis, a catalyst postulates a substitute reaction pathway. The pathway offered is of lower activation energy. Hence, there are more molecules available to overcome the activation energy barrier with the result of increased reaction rate. In fact the increase in the temperature does not change the activation energy rather changes (increase) the amount of energy the molecules have. Imagine the Boltzmann distribution diagrams to conceptualize the number of molecules with a specific amount of energy. The area under the curve in the distribution with energy more than the activation energy required indicates the number of molecules that can react to give a product. Adding a catalyst or increasing the temperature of reaction will increase the rate of reaction. For a normal reaction, it has been observed that a ten-degree centigrade rise in temperature will increase the activity of most enzymes by 50 to $100 \%$. Enzymatic catalysis is complicated because the catalyst and reactants are almost at the same temperature. Increasing the temperature of the catalyst means increasing the temperature throughout the reaction system. Increase in temperature brings no changes to the chemical structure of cellulose substrate, but it will affect the cellulases and their activities. Baig (2016a) observed that the increase in temperature from $25{ }^{\circ} \mathrm{C}$ to $40{ }^{\circ} \mathrm{C}$ could not bring any significant change on the reaction. Increasing the temperature from 25 to $50{ }^{\circ} \mathrm{C}$ was associated with almost $10 \%$ decrease in reaction rates. Some other researchers have observed similar behavior in enzymatic catalytic reaction (Tomme et al. 1990; Lee 1999). This increase in temperature brings no changes in the chemical structure of cellulose substrate and the increased temperature creates conformational changes in cellulases, such as folding, consequently, cellulases cannot remain adsorbed due to these conformational changes on the commercial cellulose (Avicel PH 101) and the adsorption is decreased. Therefore, it can be concluded that the increase in temperature affects the adsorption one way or the other. The catalysis of lignocellulosic material by an enzyme would be at a predetermined, specific range and optimized temperature.

The kinetics of catalytic reactions is almost the same as that of characteristic chemical reactions. The frequency of contact of the reactants molecules determines the rate of reactions. There is a pre-activation step in enzymatic catalytic reactions, which involves an induction period. For example, the contact time required for methane and carbon mono oxide is less than $1000 \mathrm{~s}$ while it is around
$10,000 \mathrm{~s}$ for the reaction of aromatic and carbon dioxide (Yang et al. 2017). The contact time can be controlled by flowrate in case of a continuous flow reactor or an optimum mixing speed. A limited increase in temperature may help because conversion and consequently contact will increase. Unfortunately, higher temperatures may also lead to undesired results such as: (i) decrease in adsorption or (ii) loss of activity of enzymes or (iii) desorption, i.e., separation of adsorbed enzymes. In addition to other environmental factors, the efficiency of the reactions catalyzed by enzyme is influenced by: (i) amount of enzyme, and (ii) the amount of substrate. For a fixed enzyme amount, the adsorption increases with increasing amount of lignocellulosic substrate. This is valid up to a certain amount of substrate, any further increase for substrate no significant change in adsorption would occur. The enzyme-substrate complex formed has to be dissociated, and the active sites of the enzymes have to be freed to start the adsorption recycle again with the new substrate. At the higher substrate loading and at constant temperature and $\mathrm{pH}$, the rate of adsorption is directly related to the amount of enzyme applied.

\section{Concluding remarks}

A huge number of research efforts have been exerted towards understanding the mechanisms of adsorption of enzymes on the substrate of a biomass. However, enzymatic adsorption is not a straightforward process. In fact, the adsorption is affected by many parameters such as characteristics of the substrate material (biomass) and enzymes, adsorption environment. The experimental evaluation of the governing factors is an extremely tedious job. The proposed mechanism of the transport of enzymes to the substrate may help to understand adsorption process.

Most of the studies have a variety of mixing dynamics. A slow mixing would provide chances of more adsorption on enzymes on lignocellulosic material. The application of higher shear force to increase contact not only decreases the chances of developing interaction between enzymes and lignocellulosic materials, but also decreases the activity of enzymes.

Increase in temperature increase the reaction rates, however in the case of biomaterials and enzymes the temperature effect is very delicate. In order to develop a successful adsorption equilibrium between adsorbing and desorbing enzymes, some factors such as shear forces, temperatures, concentration of enzymes and surface properties of the lignocellulosic materials need to be evaluated. A successful equilibrium means a desired (successful) yield of the product. The kinetics of enzymatic reactions is almost the same as that of characteristic chemical catalytic reactions. 
Pretreatment of lignocellulosic materials often leads to surface heterogeneity and increased roughness. The best treatment is the one, which can provide more accessibility to enzymes with minimum loss of substrate materials.

\section{Abbreviations}

A. wentii: Aspergillus wentii; ATP: Adenosine triphosphate (ATP); BAC: Bioaffinity chromatography; BCWL: Black cotton wood lignin; $\beta$-Glucosidase: Betaglucosidase; BsEXLXI: Bacillus subtilis expansion (BsEXLX1); BSA: Bovine serum albumin; $\beta$-lg: $\beta$-Lactoglobulin; C-1: First carbon; C-4: Fourth carbon; EGs: Endoglucanases; EG I: Endoglucanase I; EG II: Endoglucanase II; CBHs: Cellobiohydrolases; CBH I: Cellobiohydrolase I; CBH II: Cellobiohydrolase II; CBD: Carbohydrate-binding domain; CD: Catalytic domain; CBM: Cellulose-binding modules; Cel 7B: Family 7 endoglucanase I, glycoside hydrolase; Cel 5A: Family 5 endocellulase, glycoside hydrolase; Cel 6A: Cellobiohydrolase II; Cel 7A: Cellobiohydrolase I; CEL: Cellulolytic enzyme lignin; CMCase: Carboxy methyl cellulase; CTC: 5-Cyano-2,3-ditolyl tetrazolium chloride; GHG: Greenhouse gas; Crl: Crystallinity Index; IEA: International Energy Agency; kDa: Kilodalton; L-EPLP: Lignin derived from ethanol-pretreated lodgepole pine; L-SELP: Lignin derived from steam exploded lodgepole pine; LTHTC: Low-temperature hydrothermal carbonization; Rpm: Revolutions per minute; SEM: Scanning electron microscopy; SP: Spruce lignin; T. reesei: Trichoderma reesei; T. viride: Trichoderma viride; T. kongii: Trichoderma kongii; T. longibrachiatum: Trichoderma longibrachiatum
\end{abstract}

\section{Acknowledgements}

Not applicable.

\section{Authors' contributions}

KSB conceptualize the idea, designed the work, conducted analysis, interrelated data and results for this work, and wrote this paper. Therefore, the author is accountable for all aspects of the work in ensuring that questions related to the accuracy or integrity of any part of the work. The author read and approved the final manuscript.

\section{Funding}

No funding was provided for this project.

\section{Availability of data and materials}

The data that support the findings of this study are available from the corresponding author (KSB), upon reasonable request.

\section{Ethics approval and consent to participate}

This research does not contain any studies on human participants or animals performed by any of the authors.

\section{Consent for publication}

I, Khurram Shahzad Baig (KSB), the corresponding author, hereby declare that that it is my study and I developed the manuscript titled 'Interaction of enzymes with lignocellulosic materials, causes, mechanism and influencing factors'.

\section{Competing interests}

The authors declare that they have no competing interests.

Received: 10 January 2020 Accepted: 30 March 2020

Published online: 07 April 2020

\section{References}

Al-Haddad M, Al-Jumaily A, Brooks J, Bartley J (2013) Biophysical effects on chronic rhinosinusitis bacterial biofilms, respiratory disease and infection-a new insight. In: Bassam H. Mahboub, IntechOpen, https:// doi.org/10.5772/53860. https://www.intechopen.com/books/respirator y-disease-and-infection-a-new-insight/biophysical-effects-on-chron ic-rhinosinusitis-bacterial-biofilms
Andersson AAM, Lampi AM, Nystrom L, Piironen V, Li L, Ward JL, Gebruers K, Courtin CM, Delcour JA, Boros D, Fras A, Dynkowska W, Rakszegi M, Bedo Z, Shewry PR, Aman P (2008) Phytochemical and dietary fibre components in barley varieties in the health grain diversity screen. J Agric Food Chem 56:9767-9776

Arantes V, Saddler JN (2011) Cellulose accessibility limits the effectiveness of minimum cellulase loading on the efficient hydrolysis of pretreated lignocellulosic substrates. Biotechnol Biofuels 4:3

Arca-Ramos A, Eibes G, Feijoo G, Lema JM, Moreira MT (2018) Enzymatic reactors for the removal of recalcitrant compounds in wastewater. Biocatal Biotransform 36(3):195-215. https://doi.org/10.1080/10242 422.2017.1315411

Baig KS (2008) Biosorption of $\mathrm{Ni}^{2+}$ and $\mathrm{Zn}^{2+}$ on wheat straw. Master's Thesis presented to School of Graduate Studies at Ryerson University, Toronto, Canada

Baig KS (2016a) Strategic adsorption/desorption of cellulases NS 50013 onto/from Avicel PH 101 and protobind 1000. Doctoral Dissertation, presented to School of Graduate Studies at Ryerson University, Toronto, Canada

Baig KS (2016b) Thermodynamics of adsorption/desorption of cellulases NS 50013 on/from Avicel PH 101 and protobind 1000. Am J Eng Res 5(2):157-165

Baig KS, Turcotte G, Doan H (2016a) Adsorption of cellulose enzymes on lignocellulosic materials and influencing factors: a review. Int J Waste Resour 6:239. https://doi.org/10.4172/2252-5211.1000239

Baig KS, Turcotte G, Doan H (2016b) Looking at adsorption of cellulases NS 50013 onto Avicel PH 101 and Protobind 1000 through isotherms and thermodynamics. Int J Waste Resour. https://doi.org/10.4172/22525211.1000222

Baig KS, Turcotte G, Doan H (2016c) Adsorption and desorption of cellulases NS 50013 onto/from avicel ph 101: a simple functional model. Int J Waste Resour. https://doi.org/10.4172/2252-5211.1000243

Bekard IB, Peter Asimakis P, Bertolini J, Dunstan DE (2011) The effects of shear flow on protein structure and function. Biopolymers 95(11):733-745. https://doi.org/10.1002/bip.21646

Beldman G, Voragen AGJ, Rombouts FM, Leeuwen MF, Pilnik W (1987) Adsorption and kinetic behaviour of purified endoglucanases and exoglucanases from Trichoderma viride. Biotechnol Bioeng 30:251-257

Berlin AB, Gilkes N, Kurabi A, Bura R, Tu M, Kilburn D, Saddler NJ (2005) Weak lignin-binding enzymes. A novel approach to improve activity of cellulases for hydrolysis of lignocellulosics. Appl Biochem Biotechnol 121-124:163-170

Bhagia S, Wyman CE, Kumar R (2019) Impacts of cellulase deactivation at the moving air-liquid interface on cellulose conversions at low enzyme loadings. Biotechnol Biofuels 12(1):1-15

Bonnin E, Alvarado C, Crépeau M, Bouchet B, Garnier C, Jamme F, Devaux M (2019) Mobility of pectin methylesterase in pectin/cellulose gels is enhanced by the presence of cellulose and by its catalytic capacity. Sci Rep. https://doi.org/10.1038/s41598-019-49108-x

Bonomo CF, Minim LA, Coimbra JSR, Fontan RCl, Mendes da Silva LH, Minim VPR (2006) Hydrophobic interaction adsorption of whey proteins: effect of temperature and salt concentration and thermodynamic analysis. J Chromatogr B 844:6-14

Borjesson J, Peterson R, Tjerneld F (2007) Enhanced enzymatic conversion of softwood lignocellulose by poly (ethylene glycol) addition. Enzyme Microb Technol 40:754-762

Brigham JS, Adney WS, Himmel ME (1996) Hemicelluloses: diversity and applications. In: Wyman CE (ed) Handbook on bioethanol: production and utilization. Taylor and Francis, Washington, DC, pp 119-142

Buntić AV, Pavlović MD, Antonović DG, Šiler-Marinković SS, DimitrijevićBranković SI (2016) Utilization of spent coffee grounds for isolation and stabilization of Paenibacillus chitinolyticus CKS1 cellulase by immobilization. Heliyon 2(8):e00146. https://doi.org/10.1016/j.heliyon.2016.e00146

Bykov I (2008) Characterization of natural and technical lignins using FTIR spectroscopy. Master's Thesis. Department of Chemical Engineering and Geosciences. Lulea University of Technology. S-971 87 Lulea

Canizo JR, Cortes-Callejas ML, Dávila-Gomez FJ, Heredia-Olea E, Perez CE, Serna-Saldívar SO (2014) Release of potentially fermentable sugars during dilute acid treatments of Bermuda grass NK37 (Cynodon dactylon) for second-generation ethanol production. J Chem Technol Biotechnol 89:1941-1947 
Coyle WT (2007) The future of biofuels: a global perspective. feature bioenergy. United State Department of Agriculture (USDA). Economic Research Service. https://www.ers.usda.gov/amber-waves/2007/november/thefuture-of-biofuels-a-global-perspective/. Accessed Nov 102019

Creagh AL, Ong E, Jervis E, Kilburn DG, Haynes CA (1996) Binding of the cellulose-binding domain of exoglucanases Cex from Cellulomonas fimi to insoluble microcrystalline cellulose is entropically driven. Proc Natl Acad Sci USA 93:12229-12234

Dahmen N, Lewandowski I, Zibek S, Weldtmann A (2019) Integrated lignocellulosic value chains in a growing bioeconomy: status quo and perspectives. GCB Bioenergy. 11:107-117. https://doi.org/10.1111/gcbb.12586

Daoud FB, Kaddour S, Sadoun T (2010) Adsorption of cellulase Aspergillus niger on a commercial activated carbon: kinetics and equilibrium studies. Colloids Surf B 75(1):93-99

Das A, Ghosh U, Mohapartra PKD, Pati BR, Mondal KC (2012) Study on thermodynamics and adsorption kinetics of purified endoglucanase (CMCase) from Penicillium notatum NCIM NO-923 produced under mixed solidstate fermentation of waste cabbage and bagasse. Braz J Microbiol. 43(3):1103-1111

Das A, Paul T, Halder SK, Jana A, Ghosh K, Maity C, Mohapatra PKD, Pati BR, Mondal KC (2013) Low cost single-step purification of endoglucanase from Aspergillus fumigatus ABK-9. Indian J Exp Biol 51:954-959

Davis K, Rover M, Brown R, Bai X, Wen Z, Jarobe LR (2016) Recovery and utilization of lignin monomers as part of the biorefinery approach. Energies 9:808. https://doi.org/10.3390/en9100808

Dhowre HS, Rajput S, Russell NA, Zelze M (2015) Responsive cell-material interfaces. Nanomedicine 10(5):14. https://doi.org/10.2217/nnm.14.222

Ding B, Wang X, Yu J (2019) Electrospinning: nanofabrication and applications. William Andrew, Norwich. https://doi.org/10.1016/c2016-0-01374-8, ISBN 978-0-323-51270-1

Djajadi DT, Jensen MM, Oliveira M, Jensen A, Thygesen LG, Pinelo M, Glasius M, Jørgensen H, Meyer AS (2018) Lignin from hydrothermally pretreated grass biomass retards enzymatic cellulose degradation by acting as a physical barrier rather than by inducing nonproductive adsorption of enzymes. Biotechnol Biofuels 11(1):85

Donaldson L, Vaidya A (2017) Visualising recalcitrance by colocalisation of cellulase, lignin and cellulose in pretreated pine biomass using fluorescence microscopy. Sci Rep. 7:44386. https://doi.org/10.1038/srep44386

Dong M, Wang S, Xu F, Wang J, Yang N, Li Q, Chen J, Li W (2019) Pretreatment of sweet sorghum straw and its enzymatic digestion: insight into the structural changes and visualization of hydrolysis process. Biotechnol Biofuels. https://doi.org/10.1186/s13068-019-1613-6

Du R, Su R, Zhang M, Qi W, He Z (2014) Cellulase recycling after high-solids simultaneous saccharification and fermentation of combined pretreated corncob. Front Energy Res. https://doi.org/10.3389/fenrg 2014.00024

Duan YH, Ma YY, Zhao XD, Huang RL, Su RX, Qi W, He ZM (2018) Real-time adsorption and action of expansin on cellulose. Biotechnol Biofuels 1:317. https://doi.org/10.1186/s13068-018-1318-2

Dutta S, Chakraborty S (2016) Pore-scale dynamics of enzyme adsorption, swelling and reactive dissolution determine sugar yield in hemicellulose hydrolysis for biofuel production. Sci Rep 6:38173. https://doi org/10.1038/srep38173

Eckard AD, Muthukumarappan K, Gibbons W (2013) A review of the role of amphiphiles in biomass to ethanol conversion. Appl Sci. 3:396-419. https://doi.org/10.3390/app3020396

Eggeman T, Elander RT (2005) Process and economic analysis of pretreatment technologies. Bioresour Technol 96(18):2019-2025

Engler AJ, Chan M, Boettiger D, Schwarzbauer JE (2009) A novel mode of cell detachment from fibrillar fibronectin matrix under shear. J Cell Sci 122:1647-1653. https://doi.org/10.1242/jcs.040824

Faccio G (2018) From protein features to sensing surfaces. Sensors 18(4):1204

Feller BE, Kellis JT, Cascao-Pereira LG, Robertson CR, Frank CW (2010) The role of electrostatic interactions in protease surface diffusion and the consequence for interfacial biocatalysis. Langmuir 26(24):18916-18925. https //doi.org/10.1021/la103080a

Filali L, Brahmi Y, Sib JD, Bouizem Y, Benlakehal D, Zellana K, Lemee N, Bouhekka A, Kail F, Kebab A, Chahed L (2019) Local surface electric field's effect on adsorbed proteins' orientation. Surfaces 2:415-431. https://doi.org/10.3390/surfaces2020030
Fulton L, Howes T, Hardy J (2004) Biofuels for transport: an international perspective. International Energy Agency, Paris. http://www.iea.org/textb ase/nppd/free/2004/biofuels2004.pdf

Gosselink RJA, Abächerli A, Semke H, Malherbe R, Käuper P, Nadif A, van Dam JEG (2004) Analytical protocols for characterisation of sulphur-free lignin. Ind Crops Prod 19:271-281

Hanefeld U, Gardossi L, Magner E (2009) Understanding enzyme immobilisation. Chem Soc Rev 38:453. https://doi.org/10.1039/b711564b

Hefford MA, Laderoute K, Willick GE, Yaguchi M, Seligy VL (1992) Bipartite organization of the Bacillus subtilis endo-1, 4-glucanase revealed by C-terminal mutations. Protein Eng 5:433-439

Hermann J, DiStasio RA, Tkatchenko A (2017) First-principles models for van der Waals interactions in molecules and materials: concepts, theory, and applications. Chem Rev 117(6):4714-4758

Hilden L, Johansson G (2004) Recent developments on cellulases and carbohydrate-binding modules with cellulose affinity. Biotechnol Lett 26:1683-1693

Hoarau M, Badieyan S, Marsh ENG (2017) Immobilized enzymes: understanding enzyme-surface interactions at the molecular level. Org Biomol Chem 15:9539-9551. https://doi.org/10.1039/C7OB01880K

Hopkins WG, Huner NPA (2017) Introduction to plant physiology, 4th edn. Wiley, New York

Hoshino E, Kanda T, Sasaki Y, Nisizawa K (1992) Adsorption mode of exocellulases and endocellulases from Irpex lacteus (Polyporus tulipiferae) on cellulose with different crystallinities. J Biochem 111:600-605

Houston R, Labbe N, Hayes D, Daw CS, Abdoulmoumine (2019) Intermediate temperature water-gas shift kinetics for hydrogen production. React Chem Eng 4:1814-1822

IEA (2019) Tracking transport. IEA, Paris. https://www.iea.org/reports/trackingtransport-2019. Accessed Jan 152020

Ingesson H, Zacchi G, Yang B, Esteghlalian AR, Saddler JN (2001) The effect of shaking regime on the rate and extent of enzymatic hydrolysis of cellulose. J Biotechnol 88:177-182

loelovich M (2014) Waste paper as promising feedstock for production of biofuel. J Sci Res Rep 3(7):905-916

Isikgor FH, Becer CR (2015) Lignocellulosic biomass: a sustainable platform for the production of bio-based chemicals and polymers. Polym Chem 6:4497-4559. https://doi.org/10.1039/C5PY00263J

Jager G, Wu Z, Garscchammer K, Engel P, Klement T, Rinaldi Spiess AC, Buchs J (2010) Practical screening of purified cellobiohydrolases and endoglucanases with a cellulose and specification of hydrodynamics. Biotechnol Biofuels 3(18):1-12. https://doi.org/10.1186/1754-6834-3-18

Jalak J, Väljamäe P (2014) Multi-mode binding of Cellobiohydrolase Cel7A from Trichoderma reesei to cellulose. PLOS ONE 9(9):e108181

Jaspe J, Hagen SJ (2006) Do protein molecules unfold in a simple shear flow? Biophys J 91 (9):P3415-P3424

Jung SJ, Kim S-H, Chung I-M (2015) Comparison of lignin, cellulose, and hemicellulose contents for biofuels utilization among 4 types of lignocellulosic crops. Biomass Bioenergy 83:322-327

Kadic A, Palmqvist B, Liden G (2014) Effects of agitation on particle-size distribution and enzymatic hydrolysis of pretreated spruce and giant reed. Biotech Biofuel 7:77. https://doi.org/10.1186/1754-6834-7-77

Kang L (2011) Bioconversion of pulp and paper mills sludge and pehydrolysate stream into ethanol and cellulase enzyme. Ph.D. Dissertation, Auburn University, Albama, USA

Katsikogianni M, Missirli YF (2004) Concise review of mechanism of bacterial adhesion to biomaterials and of techniques used in estimating bacteria-material interaction. Eur Cells Mater 8:37-57. https://doi. org/10.22203/eCM.v008a05

Katsimpouras C, Kalogiannis KG, Kalogiannis A, Lappas AA, Topakas E (2017) Production of high concentrated cellulosic ethanol by acetone/water oxidized pretreated beech wood. Biotechnol Biofuels 10:54

Khattab SMR, Watanbe T (2019) Bioethanol from sugarcane bagasse: status and perspectives. Bioethanol production from food crops, sustainable sources, interventions, and challenges. Academic Press, New York, pp 187-212. https://doi.org/10.1016/B978-0-12-813766-6.00010-2

Khodaverdi M, Jeihanipour A, Karimi K, Taherzadeh MJ (2012) Kinetic modeling of rapid enzymatic hydrolysis of crystalline cellulose after pretreatment by NMMO.J J nd Microbiol Biotechnol 39:429-438. https://doi org/10.1007/s10295-011-1048-y 
Kim DW, Hong YG (2000) lonic strength effect on adsorption of cellobiohydrolases I and II on microcrystalline cellulose. Biotechnol Lett 22:1337-1342

Kim HW, Han S, Kim W, Lim J, Kim DS (2016) Modulating wall shear stress gradient via equilateral triangular channel for in situ cellular adhesion assay. Biomicrofluidics 10:054119

Klemm D, Heublein B, Finl H, Bohn A (2005) Cellulose: fascinating biopolymer and sustainable raw material. Angew Chem Int Ed 44:3358-3393

Kulkarni C, Bejagam KK, Senanayak SP, Narayan KS, Balasubramanian S, George SJ (2015) Dipole-moment-driven cooperative supramolecular polymerization. J Am Chem Soc 137:3924-3932. https://doi.org/10.1021/ jacs.5b00504

Kumar R, Wyman CE (2008) An improved method to directly estimate cellulase adsorption on biomass solids. Enzyme Microb Technol 42:426-433

Kumar P, Barrett DM, Delwiche MJ, Stroeve P (2009) Methods for pretreatment of lignocellulosic biomass for efficient hydrolysis and biofuel production. Ind Eng Chem Res 48(8):3713-3729

Kwon S, Lee JH, Kim CM, Jang H, Yun H, Jeon JJ, So I, Park HH (2019) Structural basis of substrate recognition by a novel thermostable (S)-enantioselective $\omega$-transaminase from Thermomicrobium roseum. Sci Rep 9:6958

Lara-Serrano M, Morales-delaRosa S, Campos-Martín JM, Fierro JLG (2019) Fractionation of lignocellulosic biomass by selective precipitation from ionic liquid dissolution. Appl Sci 9:1862-1879. https://doi.org/10.3390/ app9091862

Le Costaouec T, Pakarinen A, Varnai A, Puranen T, Viikari L (2013) The role of carbohydrate binding module (CBM) at high substrate consistency: comparison of Trichoderma reesei and Thermoascus aurantiacus Cel7A (CBHI) and Cel5A (EGII). Bioresour Technol 143:196-203

Lee S (1999) Molecular adsorption at solid/liquid interfaces using self assembled monolayer films. Ph.D. Thesis. Department of Chemical Engineering. Massachusetts Institute of Technology

Lee T, Alarcon-Correa MC, Miksch C, Hahn K, Gibbs J, Fischer GP (2014) Selfpropelling nanomotors in the presence of strong Brownian forces. Nano Lett 2014(14):2407-2412. https://doi.org/10.1021/nl500068n

Lehtio J, Sugiyama J, Gustavsson M, Fransson L, Linder M, Teeri TT (2003) The binding specificity and affinity determinants of family 1 and family 3 cellulose binding modules. Proc Natl Acad Sci USA 100:484-489

Li Y, Wang J, Liu X, Zhang S (2018) Towards a molecular understanding of cellulose dissolution in ionic liquids: anion/cation effect, synergistic mechanism and physicochemical aspects. Chem Sci 9(17):4027-4043. https://doi.org/10.1039/c7sc05392d

Lindman B, Medronho B, Alves L, Costa C, Edlund H, Norgren M (2017) The relevance of structural features of cellulose and its interactions to dissolution, regeneration, gelation and plasticization phenomena. Phys Chem Chem Phys 2017(19):23704-23718

Lippok S, Radtke M, Obser T, Kleemeier L, Schneppenheim R, Budde U, Rädler JO (2016) Shear-induced unfolding and enzymatic cleavage of full-length VWF multimers. Biophys J 110(3):545-554. https://doi. org/10.1016/j.bpj.2015.12.023

Liu R, Yu H, Huang Y (2005) Structure and morphology of cellulose in wheat straw. Cellulose 12:25-34

Liu H, Sun J, Leu S, Chen S (2016) Toward a fundamental understanding of cellulase-lignin interactions in the whole slurry enzymatic saccharification process. Biofuels Bioprod Biorefin 10:648-663

Lou H, Zhu JY, Lan TQ, Lai H, Qiu X (2013) pH-induced lignin surface modification to reduce nonspecific cellulase binding and enhance enzymatic saccharification of lignocelluloses. Chem Suspens Chem 6:919-927

Lourenco A, Pereira H (2018) Compositional variability of lignin in biomass. In: Poletto M (ed) Lignin-trends and applications. Intech Open, New York. https://doi.org/10.5772/intechopen.71208

Lu Y, Lu Y-C, Hu H-Q, Xie F-J, Wei X-Y, Fan X (2017) Structural characterization of lignin and its degradation products with spectroscopic methods. J Spectrosc. https://doi.org/10.1155/2017/8951658

Lutzen NW, Nielsen MH, Oxenboell KM, Schulein M, Stentebjerg-Olesen B (1983) Cellulases and their application in the conversion of lignocellulose to fermentable sugars. Philos Trans R Soc B 300:283-9

Lundell SJ (2018) Quantum mechanical studies of N-H...N hydrogen bonding in acetamide derivatives and amino acids. All Graduate Theses and Dissertations. 7309. Utah State University. https://digitalcommons.usu. edu/etd/7309

Machado DL, Moreira NJ, da Cruz Pradella JG, Bonomi A, Rabelo SC, da Costa AC (2015) Adsorption characteristics of cellulase and $\beta$-glucosidase on Avicel, pretreated sugarcane bagasse, and lignin. Biotechnol Appl Biochem 62(5):681-689. https://doi.org/10.1002/bab.1307

Mandels M, Weber J (1969) The production of cellulases. Adv Chem Ser 95:391-413

Mansor AM, Lim JS, Ani FN, Hashim H, Ho WS (2019) Characteristics of cellulose, hemicellulose and lignin of MD2 pineapple biomass. Chem Eng Trans 72:79-84. https://doi.org/10.3303/CET1972014

Marriot PE, Gomez LD, McQueen Mason SJ (2016) Unlocking the potential of lignocellulosic biomass through plant science. New Phytol 209:1366-1381

Matsakas L, Nitsos C, Raghavendran V, Yakimenko O, Persson G, Olsson E, Rova U, Olsson L, Christakopoulos P (2018) A novel hybrid organosolv: steam explosion method for the efficient fractionation and pretreatment of birch biomass. Biotechnol Biofuels 11(1):160. https://doi.org/10.1186/ s13068-018-1163-3

Maurer SA, Bedbrook CN, Radke CJ (2012) Cellulase adsorption and reactivity on a cellulose surface from flow ellipsometry. Ind Eng Chem Res 51(35):11389-11400. https://doi.org/10.1021/ie3008538

Medve J, Stahlberg J, Tjerneld F (1994) Adsorption and synergism of cellobiohydrolase I and II of Trichoderma reesei during hydrolysis of microcrystalline cellulose. Biotechnol Bioeng 44(9):1064-1073. https://doi. org/10.1002/bit.260440907

Mercon F, Erbes VL, Sant`Anna GL, Nobrega R (1997) Lipase immobilized membrane reactor applied to babassu oil hydrolysis. Braz J Chem Eng 14(1):1-10. https://doi.org/10.1590/S0104-66321997000100005

Mohamed N, Rainier TR Jr, Ross JM (2000) Novel experimental study of receptor-mediated bacterial adhesion under the influence of fluid shear. Biotechnol Bioeng 68(6):628-636

Mok YK (2015) The role of adsorbed enzymes in determining the hydrolysis kinetics of pretreated lignocellulosic biomass. Ph. D. Thesis. Faculty of graduate and postdoctoral studies (Forestry). University of British Columbia, Vancouver, Canada. https://open.library.ubc.ca/collection s/24/items/1.0167205/source

Nakagame S, Chandra RP, Kadla JF, Saddler JN (2011) The isolation, characterization and effect of lignin isolated from steam pretreated Douglas-fir on the enzymatic hydrolysis of cellulose. Bioresour Technol 102:4507-4517

National Forestry Data Base_Annual Inventory (2017) http://nfdp.ccfm.org/ en/index.php. Accessed 1 Mar 2020

Navarro-Sanchez J, Almora-Barrios N, Lerma-Berlanga B, Ruiz-Pernía JJ, LorenzFonfria VA, Tunon I, Marti-Gastaldo C (2019) Translocation of enzymes into a mesoporous MOF for enhanced catalytic activity under extreme conditions. Chem Sci 10:4082-4088. https://doi.org/10.1039/C9SC0 $0082 \mathrm{H}$

Netrabukkana R, Lourvanij K, Rorrer GL (1996) Diffusion of glucose and glucitol in microporous and mesoporous silicate/alumino silicate catalysts. Ind Eng Chem Res 35(2):458-464

Nghiem NP, Toht MJ (2019) Pretreatment of sweet sorghum bagasse for ethanol production using $\mathrm{Na}_{2} \mathrm{CO}_{3}$ obtained by $\mathrm{NaOH}$ absorption of $\mathrm{CO}_{2}$ generated in sweet sorghum juice ethanol fermentation. Fermentation 5(4):91. https://doi.org/10.3390/fermentation5040091

Nidetzky B, Steiner W (1993) A new approach for modeling cellulase-cellulose adsorption and the kinetics of the enzymatic hydrolysis of microcrystalline cellulose. Biotechnol Bioeng 42(4):469-479

Nimlos MR, Matthews JF, Crowley MF, Walker RC, Chukkapalli G, Brady JW, Adney WS, Cleary JM, Zhong L, Himmel ME (2007) Molecular modeling suggests induced fit of Family I carbohydrate-binding modules with a broken-chain cellulose surface. Protein Eng Des Sel 20(4):179-187

Nitsos CK, Lazaridis PA, Mach-Aigner A, Matis KA, Triantafyllidis KS (2019) Enhancing lignocellulosic biomass hydrolysis by hydrothermal pretreatment, extraction of surface lignin, wet milling and production of cellulolytic enzymes. Chemsuschem 12(6):1179-1195

O'Sullivan AC (1997) Cellulose: the structure slowly unravels. Cellulose 4:173-207

Ooshima H, Sakata M, Harano Y (1983) Adsorption of cellulase from Trichoderma viride on cellulose. Biotechnol Bioeng 25:3103-3114

Palmqvist B, Wiman M, Lidén G (2011) Effect of mixing on enzymatic hydrolysis of steam-pretreated spruce: a quantitative analysis of conversion and power consumption. Biotechnol Biofuels 4:10. https://doi. org/10.1186/1754-6834-4-10 
Palonen H, Tenkanen M, Linder M (1999) Dynamic interaction of Trichoderma reesei cellobiohydrolases Cel6A and Cel7A and cellulose at equilibrium and during hydrolysis. Appl Environ Microbiol 65:5229-5233

Pareek N, Gillgren T, Jönsson LJ (2013) Adsorption of proteins involved in hydrolysis of lignocellulose on lignins and hemicelluloses. Bioresour Technol 148:70-77

Park D, Jhon DY, Lee CW, Ryu SH, Rhee SG (1993) Removal of the carboxyl-terminal region of phospholipase C-beta 1 by calpain abolishes activation by G alpha q. J Biol Chem 268:3710-3714

Pauly M, Keegstra K (2008) Cell-wall carbohydrates and their modification as a resource for biofuels. Plant J 54:559-568

Piccolo C, Wiman M, Bezzo F, Liden G (2010) Enzyme adsorption on SO2 catalyzed steam-pretreated wheat and spruce material. Enzyme Microb Technol 46:159-169

Podgorbunskikh EM, Bychkov AL, Lomovsky OI (2019) Determination of surface accessibility of the cellulose substrate according to enzyme sorption. Polymers 11:1201. https://doi.org/10.3390/polym11071201

Qin Z, Buehler MJ (2014) Molecular mechanics of mussel adhesion proteins. J Mech Phys Solids 62:19-30

Queiros CSGP, Cardoso S, Lourenço A, Ferreira J, Miranda I, Lourenço MJV, Pereira H (2019) Characterization of walnut, almond, and pine nut shells regarding chemical composition and extract composition. Biomass Convers Biorefin. https://doi.org/10.1007/s13399-019-00424-2

Qureshi N, Annous BA, Ezeji TC (2005) Biofilm reactors for industrial bioconversion processes: employing potential of enhanced reaction rates. Microb Cell Fact 4:24. https://doi.org/10.1186/1475-2859-4-24

Ragnar M, Lindgren CT, Nilvebrant N (2000) pKa-values of guaiacyl and syringyl phenols related to lignin. J Wood Chem Technol 20:277-305

Rahikainen JL, Evans JD, Mikander S, Kalliola A, Puranen T, Tamminen T, Marjamaa K, Kruus K (2013) Cellulase-lignin interactions-the role of carbohydrate-binding module and $\mathrm{pH}$ in non-productive binding. Enzyme Microb Technol 53:315-321

Ramalingam K, Aimoto S, Bello J (1992) Conformational studies of anionic melittin analogues: effect of peptide concentration, $\mathrm{pH}$, ionic strength and temperature-models for protein folding and halophilic proteins. Biopolymers 32:981-992

Reinikainen T, Teleman O, Teeri TT (1995) Effects of pH and high ionic strength on the adsorption and activity of native and mutated cellobiohydrolase I from Trichoderma reesei. Proteins Struct Funct Bioinform 22:392-403

Reis CLB, de Sousa EYA, Serpa JF, Oliveira RC, Santos JCS (2018) Design of immobilized enzyme biocatalysis: drawbacks and opportunities. Quím Nova 42:7

Reyes-Rivera J, Canché-Escamilla G, Soto-Hernández M, Terrazas T (2015) Wood chemical composition in species of Cactaceae: the relationship between lignification and stem morphology. PLoS ONE 10(6):e0130240. https://doi.org/10.1371/journal.pone.0130240

Reza M, Bertinetto C, Kesari KK, Engelhardt Peter, Ruokolainen J, Vuorinen $\mathrm{T}$ (2019) Cellulose elementary fibril orientation in the spruce S1-2 transition layer. Sci Rep 9:3869

Ribeiro M, Monteiro FJ, Ferraz MP (2012) Infection of orthopedic implants with emphasis on bacterial adhesion process and techniques used in studying bacterial-material interactions. Biomatter 2(4):176-194. https://doi.org/10.4161/biom.22905

Robert P, Nicolas A, Aranda-Espinoza S, Bongrand P, Limozin L (2011) Minimal encounter time and separation determine ligand-receptor binding in cell adhesion. Biophys J 100(11):2642-2651. https://doi. org/10.1016/j.bpj.2011.04.011

Rofiqah U, Kurniawan A, Aji RWN (2019) Effect of temperature in ionic liquids pretreatment on the structure of lignocellulose from corncob. J Phys. https://doi.org/10.1088/1742-6596/1373/1/012018

Romanczuk P, Bär M, Ebeling W, Linder B, Schimansky-Geier L (2012) Active Brownian particles: from individual to collective stochastic dynamics. Eur Phys J Spec Top. https://doi.org/10.1140/epjst/e2012-01529-y

Rosgaard L, Andric P, Dam-Johansen K, Pedersen S, Meyer AS (2007) Effect of substrate loading on enzymatic hydrolysis and viscosity of pretreated barley straw. Appl Biochem Biotechnol 143:27-40

Rutledge LR, Wetmore SD (2010) Quantum biochemistry. Wiley-VCH Verlag GmbH \& Co. KGaA, Hoboken, pp 307-336

Saini JK, Saini R, Tewari L (2015) Lignocellulosic agriculture wastes as biomass feedstocks for second-generation bioethanol production: concepts and recent developments. 3 Biotech 5(4):337-353. https:// doi.org/10.1007/s13205-014-0246-5

Scott EE, Wolf CR, Otyepka M, Humphreys SC (2016) The role of proteinprotein and protein-membrane interactions on P450 function. Drug Metab Dispos 44:576-579

Sethi B, Mishra S, Bisaria VS (1998) Adsorption characteristics of cellulases from a constitutive of Trichoderma reesei. J Indian Institute of Technology, India

Shi J, Wu D, Zhang L, Simmons BA, Singh S, Yang B, Charles E, Wyman CE (2016) Dynamic changes of substrate reactivity and enzyme adsorption on partially hydrolyzed cellulose. Biotechnol Bioeng. https://doi. org/10.1002/bit.26180

Singh J, Kaur M (2014) Partial purification of cellulase enzyme from Fusarium oxysporum by using egg white matrix. Br Biotechnol J 4(2):108-115

Singh A, Kumar PKR, Schugerl K (1991) Adsorption and reuse of cellulases during saccharification of cellulosic materials. J Biotechnol 18:205-212

Sridhar SL, Ortega JKE, Vernerey FJ (2018) A statistical model of cell wall dynamics during expansive growth. Biology. https://doi. org/10.1101/346924

Srisodusk M, Reinikainen T, Pentilla M, Teeri TT (1993) Role of the interdomain linker peptide of Trichoderma reesei cellobiohydrolase I in its interaction with crystalline cellulose. J Biol Chem 268(20):756-761

Steiner W, Sattler W, Esterbauer H (1988) Adsorption of Trichoderma reesei cellulase on cellulose: experimental data and their analysis by different equations. Biotechnol Bioeng 32:853-865

Stewart JJ, Akiyama T, Chapple C, Ralph J, Mansfield SD (2009) The effects on lignin structure of overexpression of ferulate 5-hydroxylase in hybrid poplar. Plant Physiol 150:621-635

Stuart JY, Ristoph DL (1984) Analysis of cellulose-cellulase adsorption data: a fundamental approach. Biotechnol Bioeng 27:1056-1059

Sukumaran RK, Abraham A, Mathew AK (2017) Enzymes for bioenergy. In: Sugathan S, Pradeep N, Abdulhameed S (eds) Bioresources and bioprocess in biotechnology. Springer, Singapore

Sun Y, Cheng J (2002) Hydrolysis of lignocellulosic materials for ethanol production: a review. Bioresour Technol 83(1):1-11

Taegtmeyer H (2012) Cardiomyocyte metabolism: all is in flux. Muscle: fundamental biology and mechanisms of disease, vol 1. Academic Press, New York, pp 187-202. https://doi.org/10.1016/B978-0-12-381510-1.00015-6

Tamer TM, Omer AM, Hassan M (2016) Methods of enzyme immobilization. Int J Curr Pharm Rev Res 7(6):385-392

Tervasmäki P, Sotaniemi V, Kangas J, Taskila S, Ojamo H, Tanskanen J (2017) A discretized model for enzymatic hydrolysis of cellulose in a fed-batch process. Bioresour Technol 227:112-124

Thomas CR, Geer D (2010) Effects of shear on proteins in solution. Biotechnol Lett 33(3):443-456. https://doi.org/10.1007/s10529-010-0469-4

Tokunaga Y, Nagata T, Suetomi T, Oshiro S, Kondo K, Katahira M, Watanabe T (2019) NMR analysis on molecular interaction of lignin with amino acid residues of carbohydrate-binding module from Trichoderma reesei Cel7A. Sci Rep 9:1977

Tomme P, Heriban V, Claeyssens M (1990) Adsorption of two cellobiohydrolases from Trichoderma reesei to Avicel: evidence for exoexo synergism and possible loose complex formation. Biotechnol Lett 12:525-530

Tu M, Chandra RP, Saddler JN (2007) Recycling cellulases during the hydrolysis of steam exploded and ethanol pretreated Lodgepole pine. Biotechnol Prog 23:1130-1137

Tu M, Pan X, Saddler JN (2009) Adsorption of cellulase on cellulolytic enzyme lignin from Lodgepole pine. J Agric Food Chem 57:7771-7778

Varnai A, Siikaaho M, Viikari L (2010) Restriction of the enzymatic hydrolysis of steam-pretreated spruce by lignin and hemicellulose. Enzyme Microb Technol 46:185-193

Várnai A, Viikari L, Marjamaa K, Siika-aho M (2011) Adsorption of monocomponent enzymes in enzyme mixture analyzed quantitatively during hydrolysis of lignocellulose substrates. Bioresour Technol 102(2):1220-1227 
Viikari L, Alapuranen M, Puranen T, Vehmaanperä J, Siika-Aho M (2007) Thermostable enzymes in lignocellulose hydrolysis. Adv Biochem Eng Biotechnol 108:121-145

Vladkova TG (2010) Surface engineered polymeric biomaterials with improved biocontact properties. Int J Polym Sci 2010:296094. https://doi. org/10.1155/2010/296094

Voegele E (2019) IEA predicts growth in global ethanol production through 2023. Ethanol Producer Magazine. http://ethanolproducer.com/. Accessed 14 Jan 2020

Walstra P (2001) Effect of agitation on proteins. In: Miller R (ed) Food Colloids: fundamentals of formulation. Royal Society of Chemistry, London, pp 245-254

Wang DW (2010) Optimizing enzymatic preparations of mechanical pulp through the characterization of new laccases and non-productive interactions between enzymes and lignin. Master's thesis, Department of Chemical Engineering and Applied Chemistry, University of Toronto

Wang F, Zhang D, Chen M, Weiming Y, Wang L (2019) Characteristics of corn stover components pyrolysis at low temperature based on detergent fibers. Front Bioeng Biotechnol. https://doi.org/10.3389/fbioe .2019 .00188

Wilson DB (1992) Biochemistry and genetics of Actinomycetes cellulases. Crit Rev Biotechnol 12:45-63

Wilson KA, Kellie JL, Wetmore SD (2014) DNA-protein-interactions in nature: abundance, structure, composition and strength of contacts between aromatic amino acids and DNA nucleobases or deoxyribose sugar. Nucleic Acids Res 42(10):6726-6741. https://doi.org/10.1093/nar/gku26 9

Yanagishima T, Laohakunakorn N, Keyser UF, Eiser E, Tanaka H (2014) Influence of internal viscoelastic modes on the Brownian motion of a $\lambda$-DNA coated colloid. Soft Matter 10:1738-1745. https://doi.org/10.1039/ C3SM52830H

Yang H, Coolman R, Karanjkar P, Wang H, Domath P, Chen H, Fan W, Conner WC, Mountziaris TJ, Huber G (2017) The effects of contact time and coking on the catalytic fast pyrolysis of cellulose. Green Chem 19:286-297. https://doi.org/10.1039/C6GC02239A

Yang M, Zhao W, Sing S, Simmons B, Cheng G (2019) On the solution structure of kraft lignin in ethylene glycol and its implication for nanoparticle preparation. Nanoscale Adv 1:299-304. https://doi.org/10.1039/C8NA0 $0042 \mathrm{E}$

Yarbrough JM, Mittal A, Mansfield E, Taylor LE, Hobdey SE, Sammond DW, Bomble YJ, Crowley MF, Decker SR, Himmel ME, Vinzant TB (2015) New perspective on glycoside hydrolase binding to lignin from pretreated corn stover. Biotechnol Biofuels 8:124. https://doi.org/10.1186/s1306 8-015-0397-6

Ying W, Shi Z, Yang H, Xu G, Zheng Z, Yang J (2018) Effect of alkaline lignin modification on cellulase-lignin interactions and enzymatic saccharification yield. Biotechnol Biofuels. https://doi.org/10.1186/s1306 8-018-1217-6

Yuan Y, Zhai R, Li Y, Chen X, Jin M (2018) Developing fast enzyme recycling strategy through elucidating enzyme adsorption kinetics on alkali and acid pretreated corn stover. Biotechnol Biofuels. https://doi. org/10.1186/s13068-018-1315-5

Zdarta J, Meyer AS, Jesionowski T, Pinelo M (2018) A general overview of support materials for enzyme immobilization: characteristics, properties, practical utility. Catalyst 8:92. https://doi.org/10.3390/catal8020092

Zhang Y, Hess H (2019) Enhanced diffusion of catalytically active enzymes. ACS Cent Sci 5(6):939-948. https://doi.org/10.1021/acscentsci.9b00228

Zhao K, Mason TG (2018) Assembly of colloidal particles in solution. Rep Prog Phys 18:12

Zheng Y, Zhang S, Miao S, Su Z, Wang P (2013a) Temperature sensitivity of cellulase adsorption on lignin and its impact on enzymatic hydrolysis of lignocellulosic biomass. J Biotechnol 166(3):135-145. https://doi. org/10.1016/j.jbiotec.2013.04.018

Zheng AQ, Zhao ZL, Chang S, Huang Z, Wang XB, He F, Li HB (2013b) Effect of torrefaction on structure and fast pyrolysis behavior of corncobs. Bioresour Technol 128:370-377

Zoghlami A, Paes G (2019) Lignocellulosic biomass: understanding recalcitrance and predicting hydrolysis. Front Chem. https://doi.org/10.3389/ fchem.2019.00874

\section{Publisher's Note}

Springer Nature remains neutral with regard to jurisdictional claims in published maps and institutional affiliations.

\section{Submit your manuscript to a SpringerOpen ${ }^{\odot}$ journal and benefit from:}

- Convenient online submission

- Rigorous peer review

- Open access: articles freely available online

- High visibility within the field

Retaining the copyright to your article

Submit your next manuscript at $\boldsymbol{\nabla}$ springeropen.com 